NBER WORKING PAPER SERIES

\title{
VOLATILITY AND GROWTH: \\ CREDIT CONSTRAINTS AND \\ PRODUCTIVITY-ENHANCING INVESTMENT
}

\author{
Philippe Aghion \\ George-Marios Angeletos \\ Abhijit Banerjee \\ Kalina Manova \\ Working Paper 11349 \\ http://www.nber.org/papers/w11349
NATIONAL BUREAU OF ECONOMIC RESEARCH
1050 Massachusetts Avenue \\ Cambridge, MA 02138
}

May 2005

For helpful comments and discussions, we thank Daron Acemoglu, Philippe Bacchetta, Robert Barro, Olivier Blanchard, V.V. Chari, Bronwyn Hall, Peter Howitt, Olivier Jeanne, Patrick Kehoe, Ellen McGrattan, Pierre Yared, Klaus Walde, Iván Werning, and seminar participants in Amsterdam, UC Berkeley, ECFIN, Harvard, IMF, MIT, and the Federal Reserve Bank of Minneapolis. Special thanks to Do Quoc-Anh for excellent research assistance. The views expressed herein are those of the author(s) and do not necessarily reflect the views of the National Bureau of Economic Research.

(C2005 by Philippe Aghion, George-Marios Angeletos, Abhijit Banerjee, and Kalina Manova. All rights reserved. Short sections of text, not to exceed two paragraphs, may be quoted without explicit permission provided that full credit, including () notice, is given to the source. 
Volatility and Growth: Credit Constraints and Productivity-Enhancing Investment Philippe Aghion, George-Marios Angeletos, Abhijit Banerjee, and Kalina Manova NBER Working Paper No. 11349

May 2005

JEL No. E22, E32, O16, O30, O41, O57

\begin{abstract}
$\underline{\text { ABSTRACT }}$
We examine how credit constraints affect the cyclical behavior of productivity-enhancing investment and thereby volatility and growth. We first develop a simple growth model where firms engage in two types of investment: a short-term one and a long-term productivity-enhancing one. Because it takes longer to complete, long-term investment has a relatively less procyclical return but also a higher liquidity risk. Under complete financial markets, long-term investment is countercyclical, thus mitigating volatility. But when firms face tight credit constraints, long-term investment turns procyclical, thus amplifying volatility. Tighter credit therefore leads to both higher aggregate volatility and lower mean growth for a given total investment rate. We next confront the model with a panel of countries over the period 1960-2000 and find that a lower degree of financial development predicts a higher sensitivity of both the composition of investment and mean growth to exogenous shocks, as well as a stronger negative effect of volatility on growth.
\end{abstract}

Philippe Aghion

Department of Economics

University College London

Gower Street

London, WC1 6BT

and NBER

p_aghion@harvard.edu

George-Marios Angeletos

Department of Economics

MIT

50 Memorial Drive, E51-251

Cambridge, MA 02142

and NBER

angelet@mit.edu

\author{
Abhijit Banerjee \\ MIT \\ banerjee@mit.edu \\ Kalina Manova \\ Harvard University \\ manova@fas.harvard.edu
}




\section{Introduction}

The modern theory of business cycles gives a central position to productivity shocks and the role of financial markets in the propagation of these shocks; but it takes the entire productivity process as exogenous. The modern theory of growth, on the other hand, gives a central position to endogenous productivity growth and the role of financial markets in the growth process; but it focuses on trends, largely ignoring shocks and cycles. ${ }^{1}$

The goal of this paper is to build a bridge between the two approaches; to propose and, in a limited way, test a theory of endogenous productivity growth that gives a central position to uncertainty. At the heart of our theory is a propagation mechanism - how exogenous shocks generate endogenous productivity movements - and its interaction with financial markets.

The first part of the paper develops a model that focuses on the cyclical behavior of the composition of investment as the main propagation channel; this choice is motivated by facts discussed later. Entrepreneurs engage in two types of investment activity: short-term investment takes relatively little time to build and generates output relatively fast; long-term investment takes more time to complete but contributes more to productivity growth.

With perfect credit markets, investment choices are dictated merely by an opportunity-cost effect. As long as short-term returns are more cyclical than long-term returns, the opportunity cost of long-term investment is lower in recessions than in booms. ${ }^{2}$ The fraction of savings allocated to long-term investment is therefore countercyclical and, by implication, the endogenous component of productivity grows faster when coming out of a recession than otherwise.

But with sufficiently imperfect credit markets, long-term investment becomes procyclical and the business cycle is now amplified. This is not so much because borrowing constraints limit the ability to invest; in our model the interest rate adjusts in general equilibrium so that neither type of investment is constrained ex ante. It is rather because tighter constraints imply a higher risk that long-term investment will be interrupted by some (idiosyncratic) liquidity shock ex post. This risk in turn reduces the entrepreneurs' willingness to engage in long-term investment ex ante - and the more so in recessions, when liquidity is expected to be scarce. Aggregate shocks therefore have a more pronounced effect on productivity growth when credit markets are less effective.

The second part of the paper confronts the implications of the model with the data. We first examine whether there is evidence of amplification per se. For that purpose, we look at a panel of about 60 countries over the 1960-1995 period and use export-weighted commodity price shocks as our measures of exogenous shocks to the economy. We find the negative growth impact of an adverse price shock, especially at two lags, to be stronger in countries with tighter credit.

\footnotetext{
${ }^{1}$ Though the idea that there is a close connection between productivity growth and the business cycle goes back at least to Schumpeter, Hicks, and Kaldor in the 1940s-1950s.

${ }^{2}$ An opportunity-cost effect of this kind has emphasized by Aghion and Saint-Paul (1998) and more recently by Barlevy (2004).
} 
Financial development in these regressions does not appear to be capturing the role of other policies or institutions. The interaction between shocks and private credit remains significant once we control for the interaction between shocks and intellectual property rights, government expenditures, inflation, and the black-market premium.

We next examine the transmission channel by looking at the response of the rate and the composition of investment to shocks. For that purpose, we proxy the fraction of long-term productivityenhancing investments by the ratio of $R \& D$ to total investment. Data availability then limits the analysis to a panel of 14 OECD countries over the 1973-1999 period. Consistent with the predictions of our model, we find that the composition of investment is more sensitive to shocks when the level of private credit is lower. On the other hand, and in contrast to the standard credit-multiplier paradigm (e.g., Bernanke and Gertler, 1989), we find no evidence that the total rate of investment is more responsive to shocks when private credit lower.

While we are probably the first to look at the effects of shocks on the composition of investment and thereby on growth in the presence of financial constraints, there is a literature that looks at the related but distinct question of how volatility affects growth. Most notably, Ramey and Ramey (1995) find a negative relation between the two in cross-country data; this relation is robust to various controls, perhaps suggesting a negative causal effect of volatility on growth. ${ }^{3}$

Such a causal effect of volatility on growth would be consistent with the neoclassical growth paradigm if volatility discourages the demand for investment more than it encourages the precautionary supply of savings. In an $A K$ economy, for example, the general-equilibrium impact of aggregate risk on savings and thereby on growth is negative if the elasticity of intertemporal substitution is higher than one (Jones, Manuelli and Stacchetti, 2000). ${ }^{4}$

It is however unclear that this is the right explanation for the observed correlation. First, the impact of volatility persists even after we control for the aggregate investment rate. This is shown in columns 1-4 of Table 1, which repeat some of Ramey and Ramey's (1995) basic specifications in our data set. For example, in the specification that includes initial income, education, and policy and demographics variables as in Levine et al. (2000), the point estimate of the volatility coefficient falls from -0.26 to -0.22 when the investment rate is included in the controls. Prima facie, this finding suggests that the main channel through which volatility affects growth is not the overall propensity to save - one reason why we chose to focus on the composition of investment.

\section{[insert Table 1 here]}

\footnotetext{
${ }^{3}$ Similar evidence is provided by Blattman, Hwang and Williamson (2004), Koren and Tenreyro (2004), and our own results in Section 5.4. Chatterjee and Shukayev (2005), however, argue that this relation is not always robust to different regression specifications or country samples.

${ }^{4}$ The results in Angeletos (2004) suggest that the relevant threshold for the elasticity of intertemporal substitution may be quite lower in a neoclassical economy where, unlike in an $A K$ economy, capital is not the only source of income.
} 
Second, the relation may be partly spurious, driven by the effect that financial development - a factor that Ramey and Ramey did not control for - has on both growth and volatility. This point is consistent with our model, where tighter credit constraints imply a lower and a more procyclical long-term investment and therefore a slower and more variable growth process. It is also consistent with the standard credit-multiplier paradigm, which proposes that financial frictions amplify the business cycle via their effect on the variability of aggregate investment. But whereas there is evidence that credit predicts growth and volatility, a first pass of the data shows no indication that credit predicts the variability of the investment rate.

In our sample, the cross-country correlation between the mean growth rate and the ratio of private credit to GDP (the measure of financial development usually used in the literature) is 0.40 ; the correlation between the volatility of the growth rate and private credit is -0.48 . As shown in columns 5 and 6 of Table 1, the effect of credit on volatility is robust to various controls; the same is true for mean growth (see Levine, 1997, for a review). By contrast, the correlation between private credit and the standard deviation of the rate of investment to GDP is nearly zero (only -0.09); and when in columns 7 and 8 of Table 1 we repeat the same regressions as in columns 5 and 6 now using the standard deviation of the investment rate as the dependent variable, we find no relationship between the latter and the quality of the financial sector - another reason why we chose to focus on the composition rather than the rate of investment as the main transmission channel.

At the end of the empirical section we thus revisit the relation between volatility and growth in the cross-section. We find that the effect of volatility on growth survives when we control for the level of financial development, leaving open the possibility that volatility has a causal effect on growth (or, of course, that there may be some other omitted variable not captured by private credit and the other controls). In our model, the causal effect can go either direction, partly because the effect of aggregate volatility on the level of idiosyncratic liquidity risk is ambiguous in general. An interesting possibility, however, emerges in examples where liquidity risk increases with aggregate volatility. Higher volatility then discourages long-term investment and slows down growth, and the more so the tighter the credit constraints. Consistent with this possibility, we find in our sample that the negative relation between volatility on growth tends to be stronger in countries with lower financial development. This finding, however, should be taken with caution, for it looses significance when we instrument volatility with the standard deviation of commodity price shocks.

Related literature. The growth and amplification effects of financial frictions have been the subject of a large literature, including Bernanke and Gertler (1989), Banerjee and Newman (1991), King and Levine (1993), Obstfeld (1994), Kiyotaki and Moore (1997), Holmstrom and Tirole (1998), Aghion, Banerjee and Piketty (1999). ${ }^{5}$ We depart from this earlier work by focusing on how liquidity risk interacts with the horizon of investment and how this in turn affects the

\footnotetext{
${ }^{5}$ See Levine (1997) for an excellent review and more references.
} 
cyclical composition of investment. Angeletos (2004) also considers how idiosyncratic risk affects the cyclical allocation of investment, but focuses on private versus public equity.

King and Rebelo (1993), Stadler (1990), and Jones, Manuelli and Stacchetti (2000) analyze the relation between volatility and growth within the $A K$ class of models, but do not consider the cyclical behavior of the allocation of investment nor the role of financial markets. Hall (1991), Gali and Hammour (1991), Aghion and Saint-Paul (1998), and Barlevy (2004) examine the cross-sectoral allocation of investment, but assume perfect capital markets, thus bypassing the interaction effects identified here. ${ }^{6}$

Related are also Caballero and Hammour (1994) and Acemoglu and Zilibotti (1997). The first paper examines the implications of adjustment costs for volatility and the cleansing effect of recessions. The second argues that lower levels of income, by constraining the ability to diversify sector-specific risks, may lead to both higher volatility and lower growth. ${ }^{7}$ By contrast, this paper focuses on the interaction of credit constraints and the composition of investment.

The rest of the paper is organized as follows. Section 2 outlines the model. Section 3 analyzes the composition of investment and Section 4 the implications for growth and volatility. Section 5 contains the empirical analysis. Section 6 concludes.

\section{The model}

The economy is populated by overlapping generations of two-period-lived agents ("entrepreneurs"), who are indexed by $i$ and uniformly distributed over the segment $[0,1]$. In the first period of her life, an entrepreneur receives an exogenous endowment of wealth and decides how much to invest in short-term versus long-term investment. Short-term investment produces at the end of the first period, whereas long-term investment produces at the end of the second period. In between, a random liquidity shock is realized, which threatens to reduce the return of long-term investment if not financed. At the end of the second period, the entrepreneur consumes her total life-time income and dies. The life-span of an entrepreneur is illustrated in Figure 1 and further explained below.

Productivity and exogenous shocks. Aggregate productivity has two components: an exogenous and an endogenous one. We denote the endogenous component in period $t$ with $T_{t}$ and call it the level of knowledge; the determination of $T_{t}$ will be described later. The exogenous component, on the other hand, is denoted by $a_{t}$ and is assumed to follow a Markov process with support $[\underline{a}, \bar{a}] \subseteq \mathbb{R}_{+}$, unconditional mean normalized to 1 , and conditional mean $\mathbb{E}_{t-1} a_{t}=a_{t-1}^{\rho}$, where $\rho \in(0,1)$ parametrizes the persistence in exogenous productivity.

\footnotetext{
${ }^{6}$ Francois and Lloyd-Ellis (2003), on the other hand, consider a Schumpeterian growth model in which cycles are generated by firms' incentives to synchronize their innovations, as in Shleifer (1986).

${ }^{7}$ Koren and Tenreyro (2004), however, argue that, contrary to the portfolio-diversification approach, less developed countries specialize in sectors with relatively higher, not lower, risks.
} 


\begin{tabular}{|c|c|c|}
\hline pe & $d t$ & period $t+1$ \\
\hline $\begin{array}{l}\text { - } \text { productivity } a_{t} \text { is realized } \\
\text { - period- } t \text { agents are born } \\
\text { - agents borrow and lend to } \\
\text { invest in } k_{i t} \text { and } z_{i t}\end{array}$ & $\begin{array}{l}\text { - } k_{i t} \text { returns } a_{t} f\left(k_{i t}\right) \\
\text { - liquidity shock } c_{i t} \text { is realized } \\
\text { - } \text { agents borrow and lend to } \\
\text { meet liquidity shocks }\end{array}$ & $\begin{array}{l}\text { - } \text { productivity } a_{t+1} \text { is realized } \\
\text { - } z_{i t} \text { returns } a_{t+1} q\left(z_{i t}\right) \text { if liquidity } \\
\text { has been met, } 0 \text { otherwise } \\
\text { - } \text { period- } t \text { agents consume and die } \\
\text { - period- } t+1 \text { agents are born ... }\end{array}$ \\
\hline
\end{tabular}

Figure 1: The life of an entrepreuneur.

Short-term and long-term investment. Consider an entrepreneur born in period $t$. In the beginning of life, the entrepreneur receives an endowment of wealth, $W_{t}^{i}$, and decided how to allocate it between short-run investment, $K_{t}^{i}$, long-term investment, $Z_{t}^{i}$, and savings in the riskless bond, $B_{t}^{i}$. To ensure a balanced-growth path, we assume that the initial endowment and the costs of short-term and long-term investments are proportional to $T_{t}$, and denote with $w_{t}^{i}=W_{t}^{i} / T_{t}$, $k_{t}^{i}=K_{t}^{i} / T_{t}, z_{t}^{i}=Z_{t}^{i} / T_{t}$, and $b_{t}^{i}=B_{t}^{i} / T_{t}$ the "detrended" levels of wealth, short-term investment, long-term investment, and bonds holdings. We also assume that $w_{t}^{i}=w$ for some constant $w>0$, which effectively fixes the supply of savings. ${ }^{8}$ The initial budget thus reduces to

$$
k_{t}^{i}+z_{t}^{i}+b_{t}^{i} \leq w
$$

Short-term investment takes only one step to complete, namely the initial investment $K_{t}^{i}$ in the beginning of the first period, and generates output

$$
\Pi_{t}^{i}=a_{t} T_{t} \pi\left(k_{t}^{i}\right)
$$

at the end of the same period, where $\pi$ is a neoclassical production function (i.e., such that $\pi^{\prime}>$ $0>\pi^{\prime \prime}, \pi^{\prime}(0)=\infty$, and $\left.\pi^{\prime}(\infty)=0\right)$.

Long-term investment, on the other hand, takes two steps to complete: the initial investment $Z_{t}^{i}$ incurred in the beginning of the first period and an additional random adjustment $\operatorname{cost} C_{t}^{i}$ incurred at the end of the first period. Long-term investment produces

$$
\Pi_{t+1}^{i}=a_{t+1} T_{t} q\left(z_{t}^{i}\right)+C_{t}^{i}
$$

at the end of the second period if this additional cost has been met, and nothing otherwise, where $q$

\footnotetext{
${ }^{8}$ Here we are in effect ruling out any influence of the quality of financial markets the volatility of the aggregate investment rate, which is consistent with the evidence discussed in the introduction. We are also ruling out any influence on the mean investment rate; this is certainly not true in the data, but it is not important for the paper: none of the results is affected if we let $w$ be an increasing function of $\mu$.
} 
is also a neoclassical production function $\left(q^{\prime}>0>q^{\prime \prime}, q^{\prime}(0)=\infty, q^{\prime}(\infty) \leq 0\right)$. To ensure a balanced growth path, we assume that $C_{t}^{i}$ is proportional to $T_{t}$ and let $c_{t}^{i}=C_{t}^{i} / T_{t}$ be independently identically distributed across agents and periods, with support $[0, \bar{c}]$, cumulative distribution function (c.d.f) $F$, and density $f$. Unless otherwise stated, we further simplify by assuming that the c.d.f. is isoelastic: $F(c)=(c / \bar{c})^{\phi}$, with $\phi>0$.

Remarks. Note that the return to each type of investment depends on the corresponding contemporaneous productivity shock (i.e., $a_{t}$ for the short-term investment, $a_{t+1}$ for the long-term one), whereas both depend on the level of knowledge that the entrepreneur learns in the beginning of his life (i.e., $T_{t}$ ). The first assumption is essential: together with the assumption that $a_{t}$ is meanreverting, it ensures that the return to short-term investment is more cyclical than the return to long-term investment. The second assumption is less important: assuming that the output of long-term investment depends on $T_{t+1}$ rather than $T_{t}$ would not change any of the results. ${ }^{9}$ The assumption that $\Pi_{t+1}^{i}$ includes $C_{t}^{i}$ is also inessential: it simply ensures that $C_{t}^{i}$ represents a pure liquidity shock. That is, since $a_{t+1} T_{t} q\left(z_{t}^{i}\right)>0$, it is always optimal for the firm to pay the additional cost whenever it can, which in turn depends upon the efficiency of credit markets.

There are various interpretations of what the two types of investment and the liquidity shock represent. For example, the short-term investment might be putting money into one's current business, while long-term productivity-enhancing investment may be starting a new business. Or, the short-term investment may be maintaining existing equipment or buying a machine of the same vintage as the ones already installed, while the long-term investment is building an additional plant, investing in R\&D, learning a new skill, or adopting a new technology. Similarly, the liquidity shock might be an extra cost necessary for the new technology to be adapted to domestic market conditions once the new technology has been adopted; or a health problem which the entrepreneur needs to overcome or otherwise she won't be alive to enjoy the fruits of her long-term investment; or some other idiosyncratic shock that is threatening to ruin the entrepreneur's business unless she has enough liquidity to overcome it. ${ }^{10}$

Entrepreneur's payoff. The entrepreneur is risk neutral and consumes only in the last period of her life. Hence, expected life-time utility is simply $\mathbb{E}_{t}\left[W_{t+1}^{i}\right]$, where $W_{t+1}^{i}=\Pi_{t}^{i}+\left(\Pi_{t+1}^{i}-C_{t}^{i}\right) \ell_{t}^{i}+$ $\left(1+r_{t}\right) B_{t}^{i}$ is the entrepreneur's final-period wealth and $\ell_{t}^{i}$ is an indicator variable such that $\ell_{t}^{i}=1$ if the firm meets its liquidity shock and $\ell_{t}^{i}=0$ otherwise. Equivalently, the entrepreneur maximizes $\mathbb{E}_{t}\left[w_{t+1}^{i}\right]$, where

$$
w_{t+1}^{i} \equiv W_{t+1}^{i} / T_{t}=a_{t} \pi\left(k_{t}^{i}\right)+a_{t+1} q\left(z_{t}^{i}\right) \ell_{t}^{i}+\left(1+r_{t}\right) b_{t}^{i} .
$$

\footnotetext{
${ }^{9}$ This would introduce a complementarity in long-term investment across entrepreneurs, which in turn would increase its countercyclicality under complete markets and its procyclicality under tight constraints.

${ }^{10}$ The fact that long-term productivity-enhancing investments - such as setting up a new business, learning a new skill, adopting a new technology, or engaging in $R \& D$ - are largely intangible explains why a relatively large fraction of the value of such investments may not be tradeable and may therefore be lost in case the liquidity shock is not met. The assumption that everything is lost is then only for simplicity.
} 
Credit markets. Credit markets open twice every period. The "day" market takes place at the beginning of the period, before the realization of the liquidity or long-term investment adjustment cost. The "overnight" market takes place at the end of the period, after the realization of the liquidity cost.

In the day market the entrepreneur can borrow up to $m$ times her initial wealth $(m \geq 0)$. The ex ante borrowing constraint can thus be expressed as $k_{t}^{i}+z_{t}^{i} \leq \mu w$, where $\mu \equiv 1+m \geq 1$. Similarly, in the overnight market, the entrepreneur can borrow up to $m$ times her end-of-current-period wealth, $X_{t}^{i}=a_{t} T_{t} \pi\left(k_{t}^{i}\right)+\left(1+r_{t}\right) B_{t}^{i}$, for the purpose of covering the liquidity cost $C_{t}^{i}$. Thus, the probability that the entrepreneur will be able to meet the liquidity shock and enjoy the fruits of his long-term investment is given by

$$
p_{t}^{i} \equiv \operatorname{Pr}\left(C_{t}^{i} \leq \mu X_{t}^{i}\right)=F\left(\mu x_{t}^{i}\right),
$$

where $x_{t}^{i} \equiv X_{t}^{i} / T_{t}=a_{t} \pi\left(k_{t}^{i}\right)+\left(1+r_{t}\right) b_{t}^{i}$.

Finally, to simplify the analysis, we assume that wealth cannot be stored during the day, whereas overnight storage can take place at a one-to-one rate and $\bar{c} \leq \underline{a} \pi(\hat{k}(\underline{a}))$, where $\hat{k}(a)$ is the solution to $a \pi^{\prime}(\hat{k})=a^{\rho} q^{\prime}(1-\hat{k})$. The first assumption implies that the "day" interest rate $r_{t}$ will adjust so that the excess aggregate demand for the riskless bond in the day market is zero; this is equivalent to imposing the resource constraint

$$
\int_{i}\left(k_{t}^{i}+z_{t}^{i}\right)=w
$$

The second assumption ensures that the "overnight" interest rate is zero.

Endogenous growth. To complete the model, we need to describe the endogenous productivity process, that is, the dynamics of $T_{t}$. Assuming that the knowledge accumulated by one generation spills over to the next generation and identifying the knowledge produced by each entrepreneur in generation $t$ with her realized productivity, the knowledge available to generation $t+1$ is

$$
T_{t+1}=\int_{i} T_{t} q\left(z_{t}^{i}\right) \ell_{t}^{i}
$$

This is essentially the same as assuming that productivity growth is increasing in the level of productivity-enhancing investment (e.g., R\&D), as usually done in endogenous-growth models. ${ }^{11}$

\section{Cyclical composition of investment}

In this section we analyze the effect of financial development on the level and the cyclical behavior of the two types of investment. We first consider the benchmark case of complete financial markets; we then contrast it with the case of tight credit constraints.

\footnotetext{
${ }^{11}$ See for example Barro-Sala-i-Martin (1999) and Aghion-Howitt (1998).
} 


\subsection{Complete markets}

When credit markets are perfect, entrepreneurs can always meet their liquidity shocks, ensuring that long-term investment pays out with probability one. Expected wealth is thus

$$
\mathbb{E}_{t} w_{t+1}^{i}=a_{t} \pi\left(k_{t}^{i}\right)+\mathbb{E}_{t} a_{t+1} q\left(z_{t}^{i}\right)+\left(1+r_{t}\right) b_{t}^{i},
$$

which the entrepreneurs maximize with respect to $\left(k_{t}^{i}, z_{t}^{i}, b_{t}^{i}\right)$ subject to the budget constraint (1).

Obviously, all entrepreneurs make identical choices and therefore we can drop the $i$ superscripts. Since $\pi$ and $q$ are both strictly concave, the following first-order conditions are both necessary and sufficient for an optimal solution:

$$
a_{t} \pi^{\prime}\left(k_{t}\right)=1+r_{t} \quad \text { and } \quad \mathbb{E}_{t} a_{t+1} q^{\prime}\left(z_{t}\right)=1+r_{t} .
$$

It follows that the marginal rate of substitution between the two types of investment in equilibrium is given by

$$
\frac{q^{\prime}\left(z_{t}\right)}{\pi^{\prime}\left(k_{t}\right)}=\frac{a_{t}}{\mathbb{E}_{t} a_{t+1}}=a_{t}^{1-\rho}
$$

which is increasing in $a_{t}$ as long as $\rho<1$.

In equilibrium, the (day) interest rate $r_{t}$ adjusts so that the excess demand for the bond is zero, or equivalently that the resource constraint is satisfied:

$$
k_{t}+z_{t}=w
$$

This essentially imposes that the supply of savings is acyclical. ${ }^{12}$ Combining (4) and (5) implies that, in general equilibrium, an increase in $a_{t}$ reduces $z_{t}$, increases $k_{t}$ and increases $r_{t}$.

Proposition 1 Under complete markets, the share of short-term investment is procyclical, whereas the share of long-term investment is countercyclical.

Note that, by (5), the aggregate level of investment is acyclical, but its composition is not. As long as there is mean-reversion in the business cycle, profits in the immediate future (i.e., the return to short-term investment) is more sensitive to the contemporaneous state of the economy than the present value of profits anticipated further in the future (i.e., the return to long-term investment). In other words, the demand for both types of investment is procyclical, but the demand for longterm investment is less procyclical than the demand for short-term investment, which explains why in equilibrium $z_{t}$ is countercyclical under complete markets.

\footnotetext{
${ }^{12}$ That in equilibrium every entrepreneur holds no bonds follows from our assumption that all entrepreneurs are ex ante identical and that the net supply of the bond is zero.
} 
Example 1. Suppose that $\pi(k)=k^{\alpha}$ and $q(z)=z^{\alpha}, 0<\alpha<1$. Condition (4) then reduces to $\left(k_{t} / z_{t}\right)^{1-\alpha}=a_{t}^{1-\rho}$, which together with (5) implies

$$
k_{t}=\frac{a_{t}^{\eta}}{1+a_{t}^{\eta}} w \quad \text { and } \quad z_{t}=\frac{1}{1+a_{t}^{\eta}} w
$$

where $\eta=(1-\rho) /(1-\alpha)>0$. Hence, $z_{t}$ is countercyclical (i.e., decreasing in $\left.a_{t}\right)$, whereas $k_{t}$ is procyclical (i.e., increasing in $a_{t}$ ).

\section{$3.2 \quad$ Incomplete markets}

Credit constraints limit entrepreneurs' borrowing capacity to a finite multiple of their current wealth in both periods of life. The entrepreneurs' investment problem is thus given by

$$
\begin{gathered}
\max _{k_{t}^{i}, z_{t}^{i}, b_{t}^{i}}\left\{a_{t} \pi\left(k_{t}^{i}\right)+\mathbb{E}_{t} a_{t+1} q\left(z_{t}^{i}\right) F\left(\mu\left[a_{t} \pi\left(k_{t}^{i}\right)+\left(1+r_{t}\right) b_{t}^{i}\right]\right)+\left(1+r_{t}\right) b_{t}^{i}\right\} \\
\text { s.t. } \quad k_{t}^{i}+z_{t}^{i}+b_{t}^{i} \leq w, \quad k_{t}^{i}+z_{t}^{i} \leq \mu w
\end{gathered}
$$

where $F\left(\mu\left[a_{t} \pi\left(k_{t}^{i}\right)+\left(1+r_{t}\right) b_{t}^{i}\right]\right)$ is simply the probability that the liquidity shock will be met (equivalently, that long-term investment will pay out).

We assume that $\pi, q$, and $F$ are such that the objective in (6) is strictly concave; the first-order conditions are then both necessary and sufficient and all entrepreneurs make identical choices in equilibrium (so that we can again drop the $i$ subscripts). The assumption of no storage within periods implies that the first constraint is never binding in equilibrium; by the resource constraint (3), we indeed have $k_{t}+z_{t}=w<\mu w$. The first-order conditions with respect to $k_{t}^{i}$ and $z_{t}^{i}$ can then be expressed as follows:

$$
\begin{gathered}
a_{t} \pi^{\prime}\left(k_{t}\right)+\mathbb{E}_{t} a_{t+1} q\left(z_{t}\right) f\left(\mu x_{t}\right) \mu\left[a_{t} \pi^{\prime}\left(k_{t}\right)-\left(1+r_{t}\right)\right]=1+r_{t}, \\
\mathbb{E}_{t} a_{t+1} q^{\prime}\left(z_{t}\right) F\left(\mu x_{t}\right)-\mathbb{E}_{t} a_{t+1} q\left(z_{t}\right) f\left(\mu x_{t}\right) \mu\left(1+r_{t}\right)=1+r_{t},
\end{gathered}
$$

where $x_{t}=a_{t} \pi\left(k_{t}\right)+\left(1+r_{t}\right) b_{t}$. The condition for $k_{t}$ is obviously satisfied at

$$
a_{t} \pi^{\prime}\left(k_{t}\right)=1+r_{t}
$$

which means that the demand for $k_{t}$ is not affected by credit constraints. The condition for $z_{t}$, on the other hand, reduces to

$$
\mathbb{E}_{t} a_{t+1} q^{\prime}\left(z_{t}\right)=\left(1+r_{t}\right)\left[\frac{1+\mathbb{E}_{t} a_{t+1} q\left(z_{t}\right) f\left(\mu x_{t}\right) \mu}{F\left(\mu x_{t}\right)}\right]
$$

The demand for long-term investment is thus no more than under complete markets. 
In equilibrium, the interest rate $r_{t}$ adjusts so that $b_{t}=0$ and therefore $k_{t}+z_{t}=w$ and $x_{t}=a_{t} \pi\left(k_{t}\right)$. Let $\bar{\mu} \equiv \bar{c} /(\bar{a} \pi(1))$. Note that $\mu \leq \bar{\mu}$ suffices for $\mu x_{t}<\bar{c}$ to hold for all $a_{t}$, in which case $F\left(\mu x_{t}\right)<1, f\left(\mu x_{t}\right)>0$, and the term in brackets in (8) is strictly greater than one.

Proposition 2 Suppose $\mu \leq \bar{\mu}$. For any realization $a_{t}$, incomplete markets lead to a lower interest rate $r_{t}$, a higher short-term investment $k_{t}$, and a lower long-term investment $z_{t}$ as compared to complete markets.

Next consider the cyclical behavior of investment. Using $F\left(\mu x_{t}\right)=\left(\mu a_{t} \pi\left(k_{t}\right) / \bar{c}\right)^{\phi}$ along with (7), (8), and $\mathbb{E}_{t} a_{t+1}=a_{t}^{\rho}$, we infer that the equilibrium allocation of savings satisfies

$$
\frac{q^{\prime}\left(z_{t}\right)}{\pi^{\prime}\left(k_{t}\right)}=\frac{a_{t}^{1-\rho-\phi}}{\left[\mu \pi\left(k_{t}\right) / \bar{c}\right]^{\phi}}+\phi \frac{q\left(z_{t}\right)}{\pi\left(k_{t}\right)}
$$

Together with the resource constraint, $z_{t}+k_{t}=w$, the above condition implies that $z_{t}$ is increasing (decreasing) in $a_{t}$ if $1-\rho-\phi<0(>0)$.

Proposition 3 Suppose $\mu \leq \bar{\mu}$ and $\phi>1-\rho$. The share of long-term investment is now procyclical and that of short-term investment is countercyclical.

The intuition for this result is simple. The opportunity-cost effect, which tends to make the relative demand for long-term investment countercyclical, is equally present under complete and incomplete markets. But a second effect emerges when $\mu \leq \bar{\mu}$, for then the probability that the liquidity shock will not be met is less than one in all states and, most importantly, is higher in a recession than in a boom. This liquidity-risk effect tends to make the relative demand for long-term investment procyclical. The condition $\phi>1-\rho$ then ensures that this latter effect dominates: the opportunity-cost effect is weaker the higher the persistence $\rho$ in the business cycle, whereas the liquidity-risk effect is stronger the higher the cyclical elasticity $\phi$ of the probability of meeting the liquidity shock.

Finally, note that $\mu$ controls primarily the average level of liquidity risk, whereas $\phi$ controls its cyclical elasticity. Although the two parameters are unrelated in our model, lower levels of financial development may be typically associated with both a higher mean level and a higher cyclicality of liquidity risk. Moreover, in our model, the cyclicality of liquidity risk is also affected by $\mu$ when $\mu>\bar{\mu}$, for then a higher $\mu$ implies a larger region of $a_{t}$ for which the liquidity risk becomes zero and therefore becomes locally insensitive to fluctuations in $a_{t}$. For these reasons, in the empirical part of the paper we shall identify lower financial development in the data to a combination of lower $\mu$ and higher $\phi$ in the model.

Example 2. Suppose $\pi(k)=k^{\alpha}, q(z)=z^{\alpha}, \alpha<1, \bar{c}=1$, and $1-\rho<\phi<(1-\alpha) / \alpha{ }^{13}$

\footnotetext{
${ }^{13}$ The assumption $\phi<(1-\alpha) / \alpha$ suffices for the objective in (6) to be strictly concave and therefore for the first-order conditions to be sufficient.
} 

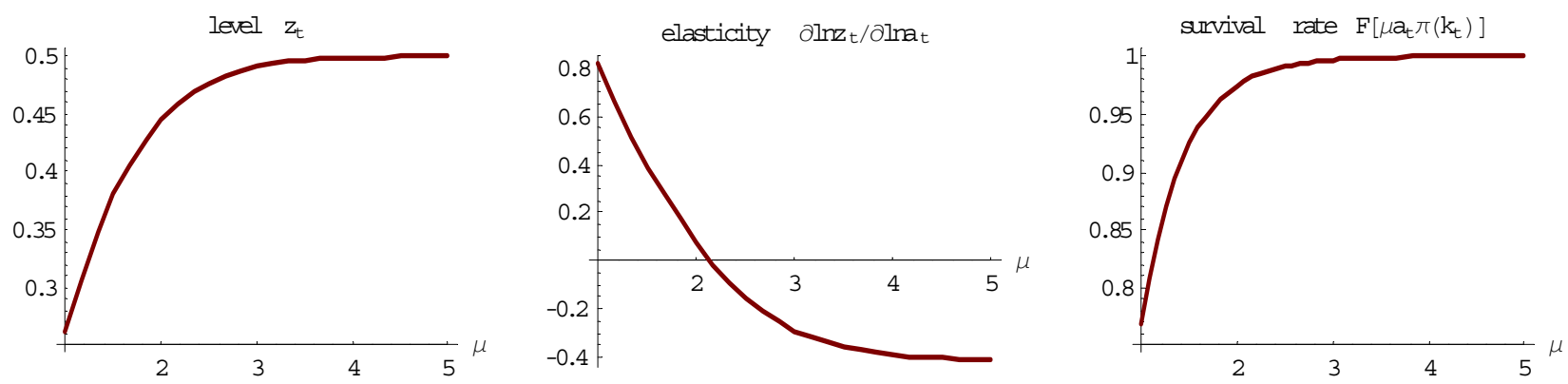

Figure 2: The effect of credit constraints $(\mu)$ on the level, the cyclical elasticity, and the survival rate of productivity-enhancing investment.

Condition (9) then reduces to

$$
\psi\left(z_{t}\right)=\mu^{\phi} a_{t}^{\phi+\rho-1}
$$

where $\psi(z)=z^{1-\alpha}(w-z)^{-\phi \alpha}(w-(1+\phi) z)^{-1}$. Clearly, $\psi(z)$ increases with $z$, whereas $\mu^{\phi} a^{\phi+\rho-1}$ increases with $\mu$ and $a$. (10) can thus be solved for $z_{t}$ as an increasing function of $\mu$ and $a_{t}$.

Example 3. Suppose the same technologies as in the above example, but now let the distribution of $c$ be log-normal, in which case the elasticity $\phi$ becomes endogenous. Figure 2 illustrates the impact of $\mu$ on the equilibrium level of long-term investment $z_{t}$, its cyclical elasticity $\partial \ln z_{t} / \partial \ln a_{t}$, and its survival rate, $\delta\left(a_{t}\right)=F\left(\mu a_{t} \pi\left(k_{t}\right)\right.$ ) (all evaluated at $a_{t}=1$ ). In this example, too, tighter constraints lead to a lower average and more procyclical long-term investment.

\section{Amplification, volatility and growth}

In this section, we analyze how financial constraints affect aggregate volatility, mean growth, and the relation between the two.

\subsection{Complete markets}

Under complete financial markets, productivity-enhancing investment is never interrupted. Hence, letting $z^{*}\left(a_{t}\right)$ denote the complete-markets equilibrium level of long-term investment, the growth rate of technology is

$$
\frac{T_{t+1}}{T_{t}}=\gamma^{*}\left(a_{t}\right) \equiv q\left(z^{*}\left(a_{t}\right)\right)
$$

Since $z^{*}\left(a_{t}\right)$ is decreasing in $a_{t}, \gamma^{*}\left(a_{t}\right)$ is also decreasing in $a_{t}$.

Corollary 1 Under complete markets, the endogenous component of productivity growth is countercyclical and therefore mitigates the business cycle. 
Consider next the causal effect of volatility on growth. Whether a higher variance in $a_{t}$ results in higher or lower mean growth ultimately depends upon the curvatures of $q(\cdot)$ and $z(\cdot)$. In the CobbDouglas case of Example 1 in Section 3.1, it is easy to check that $\gamma^{*}(\cdot)$ is necessarily convex at least in a neighborhood of the mean productivity shock. A small mean-preserving spread in $a_{t}$ starting from zero variance then necessarily increases the mean rate of technological growth. In general, however, $\gamma(\cdot)$ may have both convex and concave segments and therefore the complete-markets effect of volatility on growth is a priori ambiguous.

\subsection{Incomplete markets}

Since only those firms that can meet their adjustment costs are able to innovate and thereby contribute to aggregate productivity growth, the growth rate of technology is now given by

$$
\frac{T_{t+1}}{T_{t}}=\gamma\left(a_{t}\right) \equiv q\left(z\left(a_{t}\right)\right) \delta\left(a_{t}\right)
$$

where $z\left(a_{t}\right)$ is the incomplete-markets equilibrium level of long-term investment and $\delta\left(a_{t}\right) \equiv$ $F\left(\mu a_{t} \pi\left(w-z\left(a_{t}\right)\right)\right)$ is the equilibrium probability of covering the liquidity shock (by the law of large numbers, this is also equal to the equilibrium fraction of entrepreneurs who successfully overcome their liquidity shocks). Clearly, $\mu \leq \bar{\mu}$ and $\phi>1-\rho$ suffice for $\delta\left(a_{t}\right)<1$ and $z\left(a_{t}\right)<z^{*}\left(a_{t}\right)$ to hold for all $a_{t}$, as well as for both $\delta\left(a_{t}\right)$ and $z_{t}\left(a_{t}\right)$ to be strictly increasing in $a_{t}$. It follows that $\gamma\left(a_{t}\right)<\gamma^{*}\left(a_{t}\right)$ for all $a_{t}$, and that $\gamma\left(a_{t}\right)$ is strictly increasing in $a_{t}$.

Corollary 2 Under sufficiently incomplete markets (i.e., for $\mu \leq \bar{\mu}$ and $\phi>1-\rho$ ), the endogenous component of productivity growth is procyclical and therefore amplifies the business cycle. Moreover, productivity growth is strictly less than that under complete markets in all states.

Note how the amplification result contrasts with the mitigating effect of long-term investment under complete markets (Corollary 1). While the opportunity-cost effect implies that long-term investment and therefore productivity growth are countercyclical under complete markets, the liquidity-risk effect contributes to making productivity growth procyclical under incomplete markets via two channels: first, by imputing procyclicality in the demand for long-term investment; and second, by making the success probability of long-term investments higher in booms than in recessions.

Consider now the relationship between volatility and growth. For any given variance in $a_{t}$, a reduction in $\mu$ both increases the variance and reduces the mean of $T_{t+1} / T_{t}$. The negative cross-country correlation between growth volatility and mean growth observed in the data may therefore reflect a spurious correlation imputed by cross-country differences in financial development. Moreover, this negative correlation need not diminish once one controls for the level of aggregate investment; what matters is the composition of investment. 
The causal effect of exogenous volatility on mean growth, on the other hand, depends again on the curvatures of $q(\cdot)$ and $z(\cdot)$, as well as that of $\delta(\cdot)$. As with complete markets, the curvature of $z(\cdot)$ is ambiguous. Moreover, the curvature of $\delta(\cdot)$ depends on the distribution of the liquidity shock. The causal effect of a mean-preserving spread in $a_{t}$ on the mean of $T_{t+1} / T_{t}$ thus remains ambiguous in general. Nevertheless, the following examples provide some insight into the causal effect of volatility under incomplete markets.

Example 4. Suppose that the adjustment cost $c$ is 0 with probability $p \in(0,1)$ and $\bar{c}>0$ with probability $1-p$. Suppose further that $z\left(a_{t}\right)=\hat{z} \in(0, w)$ for all $a_{t}$, that is, ignore the cyclicality in long-term investment. Normalizing $\pi(w-\hat{z})=q(\hat{z})=1$, it follows that

$$
\gamma\left(a_{t}\right)=\delta\left(a_{t}\right)= \begin{cases}1 & \text { if } \mu a_{t} \geq \bar{c} \\ p & \text { if } \mu a_{t}<\bar{c}\end{cases}
$$

Moreover, recall that the productivity shock $a_{t}$ has unconditional mean 1 and support $[\underline{a}, \bar{a}]$.

When $\mu>\bar{c}$, firms face no liquidity risk in the absence of macroeconomic volatility (i.e., when $\underline{a}=\bar{a}=1$ ) or, more generally, as long as volatility is small enough that $\underline{a}>\bar{c} / \mu$. But as soon as $\underline{a}<\bar{c} / \mu$, a mean-preserving spread in $a_{t}$ decreases mean growth by increasing the probability that the economy will be in a (sufficiently severe) slump where a positive fraction of firms fail to meet their liquidity shocks and complete their long-term investments.

When $\mu<\bar{c}$, on the other hand, only a fraction of firms succeed in completing their long-term investments in the absence of volatility or, more generally, as long as $\bar{a}<\bar{c} / \mu$. But, as soon as $\bar{a}>\bar{c} / \mu$, a mean-preserving spread in $a_{t}$ now increases mean growth by increasing the probability that the economy will enter a sufficiently good boom where all long-term investments are completed.

This example highlights an important reason why the causal effect of volatility on growth may be non-monotonic under incomplete markets. When liquidity shocks and credit constraints are sufficiently severe that the mean probability of success is very low, higher volatility may increase mean growth by increase the chances for "resurrection"; otherwise higher volatility is likely to decrease mean growth by increasing the chances for failure.

Example 5. Suppose that $z\left(a_{t}\right)=\hat{z}$ for all $a_{t}$, as in the previous example, but now let $c$ be uniform over $[0, \bar{c}]$. Normalizing again $\pi(w-\hat{z})=q(\hat{z})=1$, we now have

$$
\gamma\left(a_{t}\right)=\delta\left(a_{t}\right)=\min \left\{\mu a_{t} / \bar{c}, 1\right\}
$$

Whereas $\delta(\cdot)$ was $S$-shaped (i.e., convex for low $a$, concave for high $a$ ) in the previous example, now it is globally concave. In other words, the resurrection effect discussed above has now disappeared. It follows that a sufficiently large mean-preserving spread in $a_{t}$ necessarily reduces mean growth. Furthermore, if $\mu>\bar{c}$, the negative effect of volatility on mean growth is higher the lower $\mu$. 

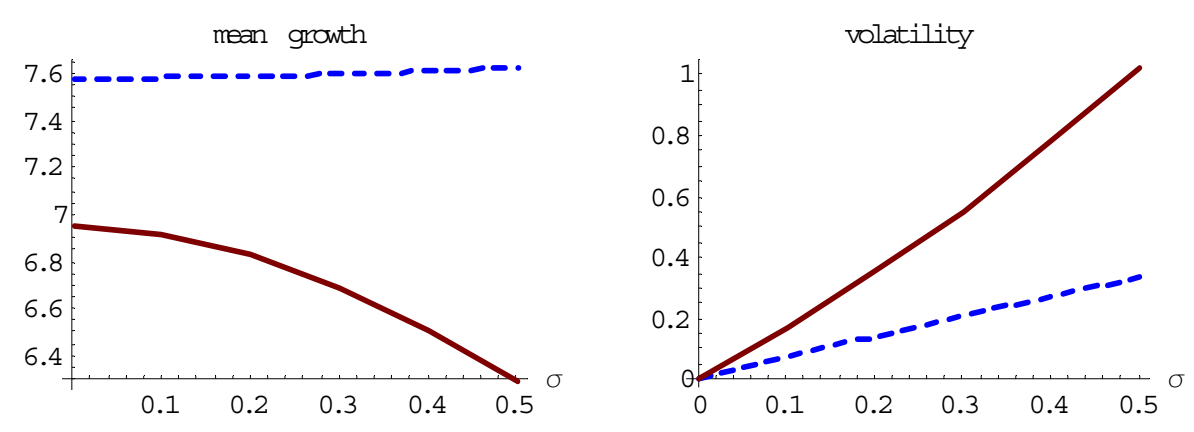

Figure 3: The effect of uncertainty $(\sigma)$ on growth and volatility; dashed lines for perfect markets, solid lines for tight credit constraints.

Example 6. Consider the same specification as in Example 3 of Section 3.2, but now assume that $\ln a_{t}$ follows a Gaussian $A R(1)$ and let $\sigma$ denote the standard deviation of the innovations in $a_{t}$. Figure 3 illustrates how the mean and the standard deviation of the growth rate $T_{t+1} / T_{t}$ vary with $\sigma$. The dashed lines represent complete credit markets $(\mu=\infty)$, whereas the solid ones correspond to incomplete markets $(\mu<\infty)$.

For any level of $\sigma$, incomplete markets are associated with lower growth and higher volatility than complete markets. Moreover, an increase in $\sigma$ has a strong negative effect on mean growth under incomplete markets. This is explained by two factors. First, the average liquidity risk is relatively small, which ensures that the resurrection effect is weak. Second, as the innovation probability $\delta(a)$ tends to be concave in $a$, the optimal level of long-term investment $z(a)$ also tends to be concave in $a$ under sufficiently incomplete markets, whereas it is convex at least in a neighborhood of the mean productivity level under complete markets; the concavity of $z(a)$ then implies that an increase in $\sigma$ tends to reduce the mean level of $z$.

\section{$5 \quad$ Empirical analysis}

In this section we test the main predictions of the model in a panel of countries over the 1960-2000 period. We construct a measure of exogenous shocks using export-weighted changes in international commodity prices, as described in detail below. We then ask whether a lower level of financial development increases the responsiveness of growth to exogenous shocks (amplification effect) and whether this effect is channeled through the rate or the composition of investment (amplification channel). We also revisit the relation between volatility and growth in the cross-section of countries.

\subsection{Data description}

As a measure of financial development we use private credit, the value of credit extended to the private sector by banks and other financial intermediaries as a share of GDP. This is a standard 
indicator in the finance and growth literature and it comes from Levine, Loyaza and Beck (2000). It is usually preferred to other measures of financial development because it excludes credit granted to the public sector and funds provided from central or development banks.

We compute annual growth as the log difference of per capita income from the Penn World Tables mark 6.1 (PWT). The measures of growth and volatility used in Tables 1 and 7 are the country-specific means and standard deviations of annual growth over the 1960-1995 period.

To study the responsiveness of the economy to exogenous shocks, we construct the following proxy. Using data on the international prices of 42 products between 1960 and 2000 from the International Financial Statistics Database of the IMF (IFS), we calculate the annual inflation/deflation rate for each commodity. We then average the share of this commodity in a country's exports in 1985, 1986, and 1987 as reported in the World Trade Analyzer (WTA). ${ }^{14}$ Finally, we take a weighted average of price changes across all commodities using the corresponding export shares as weights. We thus obtain a country-by-year-specific measure, which we call commodity-price shocks.

To test whether there is any amplification effect of financial constraints, we examine the variation in the sensitivity of growth to commodity-price shocks across different levels of financial development. To analyze the amplification channel, on the other hand, we also need data on the composition of investment. The model makes predictions for the share of long-term productivityenhancing investment; we proxy this by the share of $R \& D$ in total investment. Unfortunately, data availability limits our sample to 14 OECD countries between 1973-1999 for which the OECD reports spending on research and development in the ANBERD database. We combine this measure with data on total investment as a share of GDP from the PWT.

When analyzing the reaction of the economy to shocks we also control for overall property rights (property) and intellectual property rights $(i p r)$. The former is a broad measure from various editions of the Fraser Institute's Economic Freedom of the World database, whereas the latter is a narrower index constructed by Ginarte and Park (1997). For these variables we use the data as compiled by Caselli and Wilson (2003). ${ }^{15}$

Finally, the demographics data comes from the PWT; the schooling data from Barro and Lee (1997); and the various policy variables used in Tables 1 and 7 - the share of government in GDP, inflation, the black market exchange rate premium, and openness to trade - from Levine et al. (2000).

\subsection{Amplification effect of credit constraints}

We begin by examining the sensitivity of growth to shocks in a panel of 72 countries and 6 periods, where a period consists of 5 consecutive non-overlapping years between 1960 and 1990. We estimate

\footnotetext{
${ }^{14}$ These were the earliest years for which complete data were available at the country-commodity level.

${ }^{15}$ Data on property rights and intellectual property rights is only available at 5 -year intervals. We annualize the data by imposing a constant growth rate within each 5-year period.
} 
the following specification:

$$
\begin{aligned}
\Delta y_{i t}=\alpha_{0} & +\alpha_{1} \cdot y_{i t}+\alpha_{2} \cdot \text { shock }_{i t}+\alpha_{3} \cdot \text { credit }_{-} \\
& +\gamma \cdot \text { credit }_{i_{-}} \cdot \text { shock }_{i t}+\beta \cdot X_{i t}+\mu_{i}+\varepsilon_{i t}
\end{aligned}
$$

where $\Delta y_{i t}$ is growth for country $i$ in period $t, y_{i t}$ is beginning-of-period per capita income (in logs), and $X_{i t}$ is a vector of controls (namely, period-average population growth and secondary school enrollment). To address the potential for omitted intransient country-level variables, we include country fixed effects and cluster errors by country.

We consider two alternative measures for credit. In the first two columns of Table 2 we use the average value of private credit over the contemporaneous 5-year interval. In accordance with previous findings in the literature, we observe a negative coefficient on initial income (evidence of convergence) and a strong positive overall effect of credit. As expected, the overall impact of shock on $\Delta y$ is also positive, because an increase in shock represents an improvement in the exporting opportunities available to a country.

We are more interested, however, in the interaction of credit and shock. In line with our theoretical predictions, we find a negative coefficient, suggesting that financial development reduces the sensitivity to exogenous shocks. While the coefficient is imprecisely estimated in column 1 , it becomes statistically significant when we add time fixed effects in the second column.

\section{[insert Table 2 here]}

One concern with using the contemporaneous value of credit is that it varies with the business cycle and may thus capture the impact of some other cyclical omitted variable. Note, however, that for the interaction term to be spurious a beneficial shock must be associated with both higher growth rates and lower levels of private credit, which seems unlikely. Moreover, the estimate of $\gamma$ is robust to the introduction of either a quadratic term for shock or the interaction of $y$ and shock, which speaks further against such a bias (results not reported). Nevertheless, columns 3 and 4 repeat the estimation in the first two columns with the average value of private credit over the entire 1960-1990 period, which is immune to the above omitted variable bias. The interaction term is now highly significant with and without time fixed effects; it also increases in magnitude.

While the 1960-1990 average addresses potential bias concerns, it does not capture the significant time variation in the level of financial development; it may thus be a poorer proxy than the contemporaneous value of credit. For that reason, in the remaining of the paper we estimate all specifications with both time-variant and country-fixed measures of private credit.

Including time fixed effects, on the other hand, takes away the component in shock that is common to all countries in a given period and therefore isolates the response to the idiosyncratic component of shock. Although the empirical results suggest that the amplification effect of credit 
constraints differs between world-wide and idiosyncratic shocks, our model does not make such a distinction. To avoid taking a stance and explore the potentially differential effects of the two shock components, we continue the empirical analysis both with and without time fixed effects. ${ }^{16}$

The above results avoided the lag structure of the response of growth to shocks by aggregating over 5-year interval. We henceforth focus on an annual panel of 65 countries between 1960 and 2000 and extend the specification above as follows:

$$
\begin{aligned}
\Delta y_{i t}= & \alpha_{0}+\delta_{0} \cdot \text { shock }_{i t}+\delta_{-1} \cdot \text { shock }_{i t-1}+\delta_{-2} \cdot \text { shock }_{i t-2}+ \\
& +\gamma_{0} \cdot \text { credit }_{-} \cdot \text { shock }_{i t}+\gamma_{-1} \cdot \text { credit }_{i_{-}} \cdot \text { shock }_{i t-1}+\gamma_{-2} \cdot \text { credit }_{i_{-}} \cdot \text { shock }_{i t-2}+ \\
& +\alpha_{c} \cdot \text { credit }_{i_{-}}+\alpha_{y} \cdot y_{i t-2}+\mu_{i}+\varepsilon_{i t}
\end{aligned}
$$

Now $\Delta y$ is annual growth, $y$ is per capita income lagged two years, and the three shock variables correspond to the contemporaneous, 1-year lagged, and 2-year lagged commodity-price shocks. The estimation of all lagged shock terms is possible because of the low autocorrelation in the commodity price shocks. ${ }^{17}$ As before, we include country fixed effects and cluster errors at the country level.

Table 3 reports our results. The first column presents our baseline specification with a lagged moving average of private credit over the five years immediately preceding time $t$. As the model predicts, tighter credit results in higher sensitivity to shocks, especially at two lags. We obtain the same result when we use the 1960-2000 average value of credit in column 2 . The table also reports F-statistics for the joint significance of all three interaction terms, as well as that of only the 2 lagged interactions. In many cases, the data favor the inclusion of the interaction terms.

\section{[insert Table 3 here]}

Columns 1 and 2 restrict the sample to countries in which the moving average of private credit is always above $10 \%$ of GDP. This cut-off is motivated by the concern that variation in the measure of credit within the $0-10 \%$ range is unlikely to be informative about the variation in the availability of funds. Alternatively, financial development may not importantly affect the likelihood of meeting a liquidity shock unless it is above a minimum threshold level. When we do not impose this cut-off in columns 3 and 4 the interaction terms are less precisely estimated and lose joint significance. In contrast, the results are generally robust to higher cut-off values, such as $15 \%, 20 \%$, or $25 \%$; Columns 5 and 6 repeat the first two columns for the $20 \%$ cut-off. In light of these results, we use

\footnotetext{
${ }^{16}$ A proxy for shocks more commonly used in the growth literature is changes in the terms of trade. We prefer to use commodity-price shocks because the time variation in exchange rates that enters the terms of trade calculation is largely endogenous to the business cycle. In contrast, the time variation in the price of each commodity is largely exogenous to a country, and the weights we use to aggregate across commodities vary in the cross-section but not over time. When we use data on terms of trade shocks from Barro and Lee (1997), the interaction terms are of the correct sign but imprecisely estimated.

${ }^{17}$ We calculated the correlation coefficient between shock $k_{t}$ and $s h o c k_{t-1}$ for each country. In our sample of 65 countries the average autocorrelation coefficient was 0.08 with a standard deviation of 0.16 .
} 
the $10 \%$ cut-off throughout the rest of the analysis. ${ }^{18}$

In columns 7 and 8 we check the robustness of our results to alternative measures of private credit: a lagged moving average over the $(t-6, t-10)$ period; and the initial value of credit, computed for each country as the average of the first 5 years for which credit data are available. Both measures predate the commodity-price shocks and the length of a business cycle. Columns 9 and 10, on the other hand, add year fixed effects and thus isolate the response to idiosyncratic shocks. The results are largely unchanged, although the significance of the interaction terms varies across specifications.

We next address another omitted-variable concern: the possibility that our estimates capture the interaction effect of some other institutional variable. For example, if property rights are positively correlated with credit availability and growth reacts less to adverse shocks in countries with better property rights, the interaction terms reported in Table 3 may reflect the mitigating effect of property rights rather than that of financial development.

\section{[insert Table 4 here]}

Table 4 thus revisits the baseline specifications of Table 3 after controlling for other institutional variables. For comparison, column 1 reproduces the first column of Table 3. Column 2 adds the interactions of shock with ipr and property. Column 3 instead includes the interactions of shock with initial income $y$, a proxy for the overall level of economic development. Column 4 combines all control interactions and column 5 adds time fixed effects. Columns 6 and 7 then repeat 4 and 5 using the 1960-2000 average level of credit rather than the $(t-5, t-1)$ average. In all specifications the private-credit interaction terms remain significant. ${ }^{19,20}$

\subsection{Amplification channel}

The evidence presented so far supports the prediction that tighter credit amplifies the business cycle, but it does not identify the transmission channel as being the composition of investment or any other channel. In this subsection, we examine how credit affects the sensitivity of both the level and composition of investment to shocks. ${ }^{21}$

\footnotetext{
${ }^{18}$ When we estimate the same specification in the remaining sample of countries, which fall below the $10 \%$ cut-off, we observe highly insignificant coefficients, although usually of the same sign. We do not really know why this group of countries behaves differently; our guess is that there is simply too much noise in this group.

${ }^{19}$ Our results also survive the inclusion of the interaction of shock with the size of government and the black market premium (results not reported).

${ }^{20}$ In unreported regressions we have explored the possibility that financial development affects also the persistence of fluctuations. The interaction of private credit with $y$ enters positively, suggesting that persistence is higher in more financially developed countries. This effect however is not statistically significant.

${ }^{21}$ Walde and Woitek (2004) find that the level of R\&D expenditure tends to be procyclical in the G7 countries between 1973 and 2000. (See also Walde, 2004.) In contrast, we focus on the cyclical variation of R\&D as a share of total investment.
} 
Using annual data on 14 OECD countries between 1973 and 1999 we estimate the following two regressions:

$$
\begin{aligned}
R \& D / I_{i t}= & \alpha_{0}+\delta_{0} \cdot \text { shock }_{i t}+\delta_{-1} \cdot \text { shock }_{i t-1}+\delta_{-2} \cdot \text { shock }_{i t-2}+ \\
& +\gamma_{0} \cdot \text { credit }_{i_{-}} \cdot \text { shock }_{i t}+\gamma_{-1} \cdot \text { credit }_{i_{-}} \cdot \text { shock }_{i t-1}+\gamma_{-2} \cdot \text { credit }_{i_{-}} \cdot \text { shock }_{i t-2}+ \\
& +\alpha_{c} \cdot \text { credit }_{i_{-}}+\alpha_{y} \cdot y_{i t-2}+\mu_{i}+\varepsilon_{i t} \\
I / Y_{i t}= & \alpha_{0}+\delta_{0} \cdot \text { shock }_{i t}+\delta_{-1} \cdot \text { shock }_{i t-1}+\delta_{-2} \cdot \text { shock }_{i t-2}+ \\
& +\gamma_{0} \cdot \text { credit }_{i_{-}} \cdot \text { shock }_{i t}+\gamma_{-1} \cdot \text { credit }_{i_{-}} \cdot \text { shock }_{i t-1}+\gamma_{-2} \cdot \text { credit }_{i_{-}} \cdot \text { shock }_{i t-2}+ \\
& +\alpha_{c} \cdot \text { credit }_{i_{-}}+\alpha_{y} \cdot y_{i t-2}+\mu_{i}+\varepsilon_{i t}
\end{aligned}
$$

The dependent variables here are $R \& D$ as a share of total investment - our proxy for long-term growth-enhancing investment - and total investment as a fraction of GDP for country $i$ in year $t$. As before, we consider contemporaneous, 1-year lagged, and 2-year lagged commodity-price shocks, include country fixed effects, and cluster errors by country. Note that in the sample of countries with $\mathrm{R} \& \mathrm{D}$ data we never observe values of private credit below $10 \%$.

\section{[insert Table 5 here]}

The results from estimating (13) are reported in Table 5. Columns 1-3 use the moving average of private credit over the immediately preceding five years, whereas columns 4-6 use the 1973-1999 average for each country. Columns 2 and 5 control for the interactions of shocks with ipr, property, and per capita income lagged 2 years. Finally, year fixed effects are added in columns 3 and 6 .

Although the statistical significance of the results varies across specifications, the interaction of shocks with credit $(\gamma)$ is negative in most cases. Moreover, the total effect $(\delta+\gamma \cdot$ credit $)$ is typically positive for countries with the lowest values of credit and negative for the ones with the highest credit. In particular, we estimate statistically and economically significant negative coefficients on the interaction with once- and twice-lagged shocks when we include time effects. Once again, this suggests that the amplification channel captured in this regression is more likely to reflect the response of countries to idiosyncratic shocks than to common shocks.

\section{[insert Table 6 here]}

In sharp contrast with the above findings, when we turn to the results for (14) in Table 6, we find no evidence that tighter credit increases the sensitivity of $I / Y$ to shocks. If anything, the reverse is true: most interaction terms enter with a positive sign.

These findings are far from conclusive, since they are limited to a sample of OECD countries, a specific type of shocks and a specific decomposition of investment. Nevertheless, they appear to reject the standard amplification channel involving the level of aggregate investment, and instead point to a composition effect as in our model. 


\subsection{Revisiting the impact of volatility on growth}

As discussed in the introduction, the negative relation between volatility and growth observed in the cross-section of countries need not reflect causality. Moreover, the causal effect of volatility is ambiguous in general. An interesting possibility, however, was raised by examples 5 and 6 in Section 4: to the extent that liquidity risk increases with aggregate volatility, volatility can have a detrimental effect on growth, and the more so the tighter the credit constraints.

[insert Table 7 here]

We examine this possibility in Table 7 . In column 1 we repeat the Ramey-Ramey regression with the addition of private credit and its interaction with volatility. ${ }^{22}$ Consistent with the insight above, the negative impact of volatility on growth tends to be stronger in countries with lower financial development. This effect is economically important: in column 1, for example, a onestandard-deviation increase in the average level of financial development reduces the impact of a $1 \%$ rise in volatility by $-0.68 \%(=0.018 \cdot 38)$.

The interaction effect is robust to the inclusion of demographics, property rights and policy controls, and independent of the overall level of investment, as columns 2-4 show. It may be biased, however, because of the endogeneity of volatility. For that reason, columns 5-8 repeat the regressions instrumenting volatility with the standard deviation of commodity-price shocks. The interaction term now remains of the right sign and comparable magnitude but loses statistical significance, which may be due to the fact that commodity-price shocks explain only a small fraction of total volatility.

Further research is therefore necessary before a solid causal interpretation of the above finding can be established. ${ }^{23}$ Nevertheless, at first pass the data appear to suggest that the potentially detrimental causal effect of volatility on growth is larger in countries with lower financial development, which may have important implications for welfare and policy.

\section{Concluding remarks}

This paper investigated how financial development affects the cyclical composition of investment and the implications this has for volatility and growth. We first considered a simple model that endogenizes productivity-enhancing investment over the business cycle. We found that credit constraints make the fraction of productivity-enhancing investment more procyclical, thus amplifying the variation in productivity and output even if they fail to amplify the variation in aggregate

\footnotetext{
${ }^{22}$ For consistency we present results for the countries that meet the $10 \%$ cut-off. The results are very similar in the sample of 72 countries from Table 1.

${ }^{23}$ Supportive is also the historical evidence in Blattman, Hwang and Williamson (2004). Using panel data for 35 countries over the 1870-1939 period, they find that volatility as measured by term of trade shocks is harmful for growth in the Periphery, but not in the Core.
} 
savings. We then confronted these predictions with a cross-country panel and found evidence that tighter financial constraints make $R \& D$ investment and growth more sensitive to shocks, while also generating a more negative correlation between volatility and growth.

The model used in this paper was highly stylized. We nevertheless expect the main insights to extend to more general frameworks as long as the key propagation channel - the effect of liquidity risk on long-term productivity-enhancing investments - is preserved. An interesting direction for future research would be to embed this mechanism into a full-fledged RBC model and examine in detail the implications for the economy's impulse responses to exogenous productivity and demand shocks. ${ }^{24}$

Another fruitful direction for future research is the interplay between macroeconomic policy and productivity growth. ${ }^{25}$ Extending the insights of this paper regarding the causal effect of volatility on growth, Aghion, Barro and Marinescu (work in progress) investigate whether countercyclical budgetary policies have a stronger positive effect on long-run growth in less financially developed countries. Aghion, Bacchetta, Ranciere, and Rogoff (2005), on the other hand, examine the relationship between financial development, the choice of exchange-rate regime, and growth performance.

\section{References}

[1] Acemoglu, Daron, and Zilibotti, Fabrizio (1997), "Was Prometheus Unbound by Chance? Risk, Diversification, and Growth," Journal of Political Economy 105, 709-751.

[2] Aghion, Philippe, and Peter Howitt (1998), Endogenous Growth Theory, MIT Press, Cambridge, MA.

[3] Aghion, Philippe, and Gilles Saint-Paul (1998), "Virtues of Bad Times: Interaction Between Productivity Growth and Economic Fluctuations," Macroeconomic Dynamics 2, 322-344.

[4] Aghion, Philippe, Abhijit Banerjee and Thomas Piketty (1999), "Dualism and Macroeconomic Activity," Quarterly Journal of Economics 114, 1359-1397.

\footnotetext{
${ }^{24}$ Note that the Solow residual is endogenous: demand shocks may generate productivity shocks. This may be relevant also for the recent VAR and quantitative RBC literatures (e.g., Gali and Rabanal, 2004, Chari, Kehoe, and McGrattan 2004).

${ }^{25}$ The growth literature has so far remained relatively silent about this issue; few notable exemptions are King, Plosser and Rebelo (1988), Jones, Manuelli and Stacchetti (2000), and Easterly (2005) within the $A K$ framework.
} 
[5] Aghion, Philippe, Philippe Bacchetta, Romain Ranciere and Kenneth Rogoff (2005), "Productivity Growth and the Exchange Rate Regime: The Role of Financial Development," Harvard University mimeo.

[6] Angeletos, George-Marios (2004), "Uninsured Idiosyncratic Investment Risk and Aggregate Saving," NBER Working Paper 11180.

[7] Banerjee, Abhijit, and Andrew Newman (1993), "Occupational Choice and the Process of Development," Journal of Political Economy 101.

[8] Barlevy, Gadi (2004), "On the Timing of Innovation in Stochastic Schumpeterian Growth Models," NBER Working Paper 10741.

[9] Barro, Robert, and Jong Wha Lee (1996), "International Measures of Schooling Years and Schooling Quality," American Economic Review 86, 218-23.

[10] Barro, Robert, and Xavier Sala-i-Martin (1999), Economic Growth, MIT Press, Cambridge, MA.

[11] Bernanke, Ben, and Mark Gertler (1989), "Agency Costs, Net Worth, and Business Fluctuations," American Economic Review 79, 14-31.

[12] Blattman, Christopher, Jason Hwang, and Jeffrey Williamson (2004), "The Impact of the Terms of Trade on Economic Development in the Periphery, 1870-1939: Volatility and Secular Change," NBER Working Paper 10600.

[13] Caballero, Ricardo, and Mohamad Hammour (1994), "The Cleansing Effect of Recessions," American Economic Review 84, 1350-68.

[14] Caselli, Francesco, and Daniel Wilson (2003), "Importing Technology," Journal of Monetary Economics, forthcoming.

[15] Chari, V.V., Patrick Kehoe, and Ellen McGrattan (2004), "Are Structural VARs Useful Guides for Developing Business Cycle Theories," Federal Reserve Bank of Minneapolis Working Paper 631.

[16] Chatterjee, Partha, and Malik Shukayev (2005), "Are Average Growth Rate and Volatility Related?," University of Minnesota mimeo.

[17] Francois, Patrick, and Huw Lloyd-Ellis (2003), "Animal Spirits Through Creative Destruction," American Economic Review, 93, 530-550.

[18] Gali, Jordi, and Pau Rabanal (2004), "Technology Shocks and Aggregate Fluctuations: How Well does the RBC Model Fit Postwar U.S. Data?," NBER Macroeconomics Annual 2004. 
[19] Gali, Jordi, and Mohamad Hammour (1991), "Long-run Effects of Business Cycles," Columbia University mimeo.

[20] Gavin, M., and Ricardo Hausmann (1996), "Make or Buy: Approaches to Financial Market Integration," Inter-American Development Bank Working Paper 337.

[21] Ginarte, Juan, and Walter Park (1997), "Determinants of Patent Rights: a Cross-National Study," Research Policy 26(3), 283-301.

[22] Hall, Robert (1991), "Recessions as Reorganization," NBER Macroeconomics Annual 1991.

[23] Heston, Alan, Robert Summers, and Bettina Aten (2002), "Penn World Tables Version 6.1," Center for International Comparisons at the University of Pennsylvania.

[24] Holmstrom, Bengt, and Jean Tirole (1998), "Private and Public Supply of Liquidity," Journal of Political Economy 106, 1-40.

[25] Jones, Larry, Rodolfo Manuelli, and Ennio Stacchetti (2000), "Technology and Policy Shocks in Models of Endogenous Growth," Federal Reserve Bank of Minneapolis Working Paper 281.

[26] Kaldor, Nicholas (1954), "The Relation of Economic Growth and Cyclical Fluctuations," Economic Journal 64, 53-71.

[27] King, Robert, and Ross Levine (1993), "Finance and Growth: Schumpeter Might Be Right," Quarterly Journal of Economics 108, 717-737.

[28] King, Robert, and Sergio Rebelo (1993), "Transitional Dynamics and Economic Growth in the Neoclassical Model," American Economic Review 83, 908-31.

[29] Kiyotaki, Nobuhiro, and John Moore (1997), "Credit Cycles," Journal of Political Economy 105, 211-48.

[30] Koren, Miklos, and Silvana Tenreyro (2004), "Diversification and Development," Harvard University and Federal Reserve Bank of Boston mimeo.

[31] Levine, Ross (1997), "Financial Development and Economic Growth: Views and Agenda," Journal of Economic Literature 35, 688-726.

[32] Levine, Ross, Thorsten Beck, and Asli Demirguc-Kunt (2001), "A New Database on the Structure and Development of the Financial Sector," World Bank Economic Review.

[33] Levine, Ross, Norman Loyaza, and Thorsten Beck (2000), "Financial Intermediation and Growth: Causality and Causes," Journal of Monetary Economics 46, 31-77. 
[34] Obstfeld, Maurice (1994), "Risk-Taking, Global Diversification, and Growth," American Economic Review 84, 1310-1329.

[35] Ramey, Garey, and Valerie Ramey (1995), "Cross-Country Evidence on the Link Between Volatility and Growth," American Economic Review 85, 1138-51.

[36] Shleifer, Andrei (1986), "Implementation Cycles," Journal of Political Economy 94(6), 116390.

[37] Stadler, George (1990), "Business Cycle Models with Endogenous Technology" American Economic Review 80, 763-78.

[38] Walde, Klaus (2004), "Endogenous Growth Cycles," International Economic Review, forthcoming.

[39] Walde, Klaus, and Ulrich Woitek (2004), "R\&D Expenditure in G7 Countries and the Implications for Endogenous Fluctuations and Growth," Economics Letters 82, 91-97. 
Table 1. Average growth, growth volatility and investment volatility

\begin{tabular}{|c|c|c|c|c|c|c|c|c|}
\hline \multirow[t]{2}{*}{ Dependent variable: } & \multicolumn{4}{|c|}{ Average growth, 1960-1995 } & \multicolumn{2}{|c|}{$\begin{array}{c}\text { Growth volatility, 1960- } \\
1995\end{array}$} & \multicolumn{2}{|c|}{$\begin{array}{c}\text { Investment volatility, } \\
1960-1995\end{array}$} \\
\hline & (1) & $(2)$ & (3) & $(4)$ & (5) & $(6)$ & $(7)$ & $(8)$ \\
\hline initial income & $\begin{array}{l}-0.0019 \\
(-0.69)\end{array}$ & $\begin{array}{l}-0.0175 \\
(-5.66)^{\star * *}\end{array}$ & $\begin{array}{l}-0.0094 \\
(-3.89)^{\star * *}\end{array}$ & $\begin{array}{l}-0.0163 \\
(-5.98)^{* * *}\end{array}$ & $\begin{array}{l}-0.0063 \\
(-1.87)^{*}\end{array}$ & $\begin{array}{l}-0.0052 \\
(-1.11)\end{array}$ & $\begin{array}{l}-0.0056 \\
(-1.38)\end{array}$ & $\begin{array}{l}-0.0061 \\
(-1.01)\end{array}$ \\
\hline growth volatility & $\begin{array}{l}-0.2796 \\
(-2.63)^{\star * *}\end{array}$ & $\begin{array}{l}-0.2641 \\
(-2.78)^{* * *}\end{array}$ & $\begin{array}{l}-0.1829 \\
(-2.14)^{\star *}\end{array}$ & $\begin{array}{l}-0.2208 \\
(-2.63)^{\star *}\end{array}$ & & & & \\
\hline investment/GDP & & & $\begin{array}{l}0.1742 \\
(6.47)^{\star * \star}\end{array}$ & $\begin{array}{l}0.0963 \\
(3.96)^{* * *}\end{array}$ & & & & \\
\hline private credit & & & & & $\begin{array}{l}-0.00024 \\
(-2.45)^{\star *}\end{array}$ & $\begin{array}{l}-0.00012 \\
(-0.90)\end{array}$ & $\begin{array}{l}0.00003 \\
(0.25)\end{array}$ & $\begin{array}{l}0.00019 \\
(1.11)\end{array}$ \\
\hline Controls: & & & & & & & & \\
\hline pop growth, sec enroll & no & yes & no & yes & no & yes & no & yes \\
\hline Levine et al. policy set & no & yes & no & yes & no & yes & no & yes \\
\hline property rights & no & yes & no & yes & no & yes & no & yes \\
\hline $\begin{array}{l}\text { R-squared } \\
N\end{array}$ & $\begin{array}{l}0.0969 \\
70\end{array}$ & $\begin{array}{l}0.6018 \\
59\end{array}$ & $\begin{array}{l}0.4472 \\
70\end{array}$ & $\begin{array}{l}0.7013 \\
59\end{array}$ & $\begin{array}{l}0.2673 \\
70\end{array}$ & $\begin{array}{l}0.3755 \\
59\end{array}$ & $\begin{array}{l}0.0356 \\
70\end{array}$ & $\begin{array}{l}0.2856 \\
59\end{array}$ \\
\hline
\end{tabular}

Note: All regressors are averages over the 1960-1995 period, except for intellectual and property rights which are for 1970-1995 and 1970-1990 respectively. Initial income and secondary school enrollment are taken for 1960. Growth and investment volatility are constructed as the standard deviation of annual growth and the share of total investment in GDP in the 1960-1995 period respectively. The Levine et al. policy set of controls includes government size as a share of GDP, inflation, black market premium, and trade openness. Constant term not shown. t-statistics in parenthesis. ${ }^{* * *}, * *,{ }^{*}$ significant at $1 \%, 5 \%$, and $10 \%$. 
Table 2. The response of growth to commodity price shocks: 5-year avgs

Dependent variable: 5-year avg. growth

\begin{tabular}{|c|c|c|c|c|}
\hline \multirow[t]{2}{*}{ Private credit measure: } & \multicolumn{2}{|c|}{ private credit } & \multicolumn{2}{|c|}{ "1960-1990 avg } \\
\hline & (1) & $(2)$ & (3) & $(4)$ \\
\hline initial income & $\begin{array}{l}-0.0701 \\
(-6.60)^{\star * *}\end{array}$ & $\begin{array}{l}-0.0710 \\
(-6.00)^{* * *}\end{array}$ & $\begin{array}{l}-0.0481 \\
(-4.68)^{\star * *}\end{array}$ & $\begin{array}{l}-0.0467 \\
(-3.74)^{\star * \star}\end{array}$ \\
\hline shock & $\begin{array}{l}0.1243 \\
(2.20)^{* *}\end{array}$ & $\begin{array}{l}0.1214 \\
(2.09)^{* *}\end{array}$ & $\begin{array}{l}0.1686 \\
(2.79)^{* * *}\end{array}$ & $\begin{array}{l}0.1518 \\
(2.36)^{\star *}\end{array}$ \\
\hline private credit & $\begin{array}{l}0.0387 \\
(2.97)^{\star * \star *}\end{array}$ & $\begin{array}{l}0.0385 \\
(2.75)^{\star \star \star}\end{array}$ & & \\
\hline private credit*shock & $\begin{array}{l}-0.2119 \\
(-1.44)\end{array}$ & $\begin{array}{l}-0.2722 \\
(-1.78)^{*}\end{array}$ & $\begin{array}{l}-0.4033 \\
(-2.24)^{* *}\end{array}$ & $\begin{array}{l}-0.4103 \\
(-2.12)^{\star *}\end{array}$ \\
\hline Controls: & & & & \\
\hline pop growth, sec enroll & yes & yes & yes & yes \\
\hline country fixed effects & yes & yes & yes & yes \\
\hline period fixed effects & no & yes & no & yes \\
\hline$\overline{R \text {-squared }}$ & 0.5355 & 0.5521 & 0.4788 & 0.4925 \\
\hline \# countries (groups) & 72 & 72 & 72 & 72 \\
\hline$N$ & 388 & 388 & 418 & 418 \\
\hline
\end{tabular}

Note: Commodity price shocks are export-weighted changes in the price of 42 commodities. All variables except for private credit are averaged over 5-year non-overlapping periods from 1960 to 1990. Initial income is beginning of period income. Private credit is averaged over the concurrent 5-year period in Columns (1) and (2) and over the 19601990 period in Columns (3) and (4). All regressions include a constant term, and cluster errors at the country level. $t$ statistics in parenthesis. ${ }^{* * *},{ }^{* *},{ }^{*}$ significant at $1 \%, 5 \%$ and $10 \%$. 


\section{Table 3. The response of growth to commodity price shocks}

Dependent variable: annual growth

\begin{tabular}{|c|c|c|c|c|c|c|c|c|c|c|}
\hline \multirow{3}{*}{ Private credit average: } & \multicolumn{2}{|c|}{ "Baseline specifications } & \multicolumn{2}{|c|}{ No threshold } & \multicolumn{2}{|c|}{$20 \%$ threshold } & \multicolumn{2}{|c|}{ Other credit measures } & \multicolumn{2}{|c|}{ Year fixed effects } \\
\hline & $(t-5, t-1)$ & $1960-2000$ & $(t-5, t-1)$ & $1960-2000$ & $(\mathrm{t}-5, \mathrm{t}-1)$ & $1960-2000$ & $(\mathrm{t}-10, \mathrm{t}-6)$ & $\left(t_{0}, t_{0}+4\right)$ & $(\mathrm{t}-5, \mathrm{t}-1)$ & $1960-2000$ \\
\hline & $(1)$ & $(2)$ & (3) & (4) & (5) & (6) & $(7)$ & $(8)$ & (9) & (10) \\
\hline \multirow{2}{*}{ shock $_{t}$} & -0.0130 & 0.0110 & -0.0050 & -0.0215 & -0.0600 & -0.0272 & -0.0117 & -0.0006 & -0.0307 & -0.0022 \\
\hline & $(-0.53)$ & $(0.48)$ & $(-0.24)$ & $(-0.96)$ & $(-0.59)$ & $(-0.30)$ & $(-0.59)$ & $(-0.02)$ & $(-1.33)$ & $(-0.10)$ \\
\hline \multirow[t]{2}{*}{$\operatorname{shock}_{t-1}$} & -0.0154 & 0.0019 & 0.0208 & -0.0025 & 0.0133 & 0.0835 & -0.0256 & -0.0402 & 0.0062 & -0.0011 \\
\hline & $(-0.48)$ & $(0.05)$ & (1.01) & $(-0.08)$ & $(0.09)$ & $(0.92)$ & $(-0.67)$ & $(-1.23)$ & $(0.19)$ & $(-0.03)$ \\
\hline \multirow[t]{2}{*}{ shock $_{t-2}$} & 0.0687 & 0.0651 & 0.0487 & 0.0283 & -0.0028 & 0.0951 & 0.0575 & 0.0498 & 0.0584 & 0.0602 \\
\hline & $(2.88)^{\star * *}$ & $(2.39)^{\star \star}$ & $(2.79)^{\star * *}$ & $(1.17)$ & $(-0.03)$ & $(1.34)$ & $(2.06)^{\star \star}$ & $(1.85)^{*}$ & $(2.58)^{\star *}$ & $(2.18)^{\star *}$ \\
\hline \multirow[t]{2}{*}{ priv credit } & 0.0174 & & 0.0246 & & 0.0121 & & 0.0177 & & 0.0109 & \\
\hline & $(2.69)^{\star * *}$ & & $(2.92)^{\star * *}$ & & $(1.48)$ & & $(2.05)^{\star *}$ & & (1.63) & \\
\hline \multirow[t]{2}{*}{ priv credit*shock $_{t}$} & 0.0337 & -0.0302 & 0.0205 & 0.0849 & 0.1412 & 0.0743 & 0.0274 & 0.0091 & 0.0193 & -0.0757 \\
\hline & $(0.47)$ & $(-0.46)$ & $(0.32)$ & $(1.13)$ & $(0.94)$ & $(0.51)$ & $(0.47)$ & $(0.10)$ & $(0.28)$ & $(-1.08)$ \\
\hline \multirow[t]{2}{*}{ priv credit*shock $_{t-1}$} & -0.0177 & -0.0863 & -0.0690 & -0.0240 & -0.0533 & -0.1822 & 0.0273 & 0.0748 & 0.0014 & 0.0071 \\
\hline & $(-0.27)$ & $(-0.89)$ & $(-0.99)$ & $(-0.23)$ & $(-0.25)$ & $(-1.21)$ & $(0.29)$ & $(0.74)$ & $(0.02)$ & $(0.08)$ \\
\hline \multirow[t]{2}{*}{ priv credit $^{*}$ shock $_{t-2}$} & -0.2083 & -0.1980 & -0.1044 & -0.0556 & -0.0886 & -0.2423 & -0.1752 & -0.1936 & -0.1383 & -0.1819 \\
\hline & $(-3.05)^{* * *}$ & $(-2.43)^{\star *}$ & $(-1.72)^{*}$ & $(-0.65)$ & $(-0.59)$ & $(-1.80)^{*}$ & $(-1.96)^{*}$ & $(-1.90)^{*}$ & $(-2.04)^{\star *}$ & $(-1.94)^{*}$ \\
\hline \multicolumn{11}{|l|}{ Controls: } \\
\hline income $_{t-2}$ & yes & yes & yes & yes & yes & yes & yes & yes & yes & yes \\
\hline country fixed effects & yes & yes & yes & yes & yes & yes & yes & yes & yes & yes \\
\hline year fixed effects & no & no & no & no & no & no & no & no & yes & yes \\
\hline \multicolumn{11}{|l|}{ F-tests: } \\
\hline all interaction terms & 0.0164 & 0.1262 & 0.3955 & 0.6214 & 0.5585 & 0.1476 & 0.2108 & 0.1085 & 0.1388 & 0.1828 \\
\hline lagged interaction terms & 0.0074 & 0.0587 & 0.2294 & 0.8004 & 0.8351 & 0.1219 & 0.1099 & 0.0758 & 0.0770 & 0.1079 \\
\hline$R$-squared & 0.1739 & 0.1368 & 0.1162 & 0.0966 & 0.1935 & 0.1215 & 0.1724 & 0.1359 & 0.2317 & 0.1828 \\
\hline \# countries & 65 & 65 & 109 & 111 & 29 & 29 & 63 & 65 & 65 & 65 \\
\hline$N$ & 1,923 & 2,364 & 3,104 & 3,980 & 829 & 1,044 & 1,639 & 2,364 & 1,923 & 2,364 \\
\hline
\end{tabular}

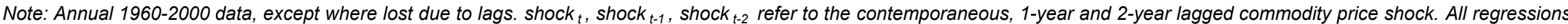
include a constant term, and cluster errors at the country level. The sample is limited to countries whose (t-5, $t-1)$ credit average is always above $10 \%$ of GDP (20\% in Columns (5) and (6)), except for Columns (3) and (4) where no threshold is imposed. $t$-statistics in parenthesis. ${ }^{* * *},{ }^{* *},{ }^{*}$ significant at $1 \%, 5 \%$, and $10 \%$. 
Table 4. The response of growth to commodity price shocks: robustness

Dependent variable: annual growth

\begin{tabular}{|c|c|c|c|c|c|c|c|}
\hline \multirow{2}{*}{$\begin{array}{l}\text { Private credit and property } \\
\text { terms average: }\end{array}$} & \multicolumn{5}{|c|}{$(\mathrm{t}-5, \mathrm{t}-1)$ avg } & \multicolumn{2}{|c|}{$1960-2000$ avg } \\
\hline & (1) & (2) & (3) & (4) & (5) & (6) & $(7)$ \\
\hline shock $_{t}$ & $\begin{array}{l}-0.0130 \\
(-0.53)\end{array}$ & $\begin{array}{l}-0.1350 \\
(-2.57)^{\star *}\end{array}$ & $\begin{array}{l}-0.0073 \\
(-0.05)\end{array}$ & $\begin{array}{l}-0.2405 \\
(-1.39)\end{array}$ & $\begin{array}{l}-0.2176 \\
(-1.16)\end{array}$ & $\begin{array}{l}0.0973 \\
(0.76)\end{array}$ & $\begin{array}{l}-0.0149 \\
(-0.14)\end{array}$ \\
\hline shock $_{t-1}$ & $\begin{array}{l}-0.0154 \\
(-0.48)\end{array}$ & $\begin{array}{l}-0.0069 \\
(-0.09)\end{array}$ & $\begin{array}{l}-0.0102 \\
(-0.07)\end{array}$ & $\begin{array}{l}0.1682 \\
(0.57)\end{array}$ & $\begin{array}{l}0.0781 \\
(0.25)\end{array}$ & $\begin{array}{l}-0.0527 \\
(-0.30)\end{array}$ & $\begin{array}{l}-0.0298 \\
(-0.18)\end{array}$ \\
\hline shock $_{t-2}$ & $\begin{array}{l}0.0687 \\
(2.88)^{\star * *}\end{array}$ & $\begin{array}{l}0.0038 \\
(0.06)\end{array}$ & $\begin{array}{l}0.2319 \\
(1.28)\end{array}$ & $\begin{array}{l}0.0682 \\
(0.30)\end{array}$ & $\begin{array}{l}-0.0597 \\
(-0.29)\end{array}$ & $\begin{array}{l}0.0846 \\
(0.59)\end{array}$ & $\begin{array}{l}0.0381 \\
(0.28)\end{array}$ \\
\hline priv credit & $\begin{array}{l}0.0174 \\
(2.69)^{\star * *}\end{array}$ & $\begin{array}{l}0.0234 \\
(2.41)^{\star *}\end{array}$ & $\begin{array}{l}0.0172 \\
(2.63)^{\star *}\end{array}$ & $\begin{array}{l}0.0235 \\
(2.42)^{\star *}\end{array}$ & $\begin{array}{l}0.0180 \\
(1.78)^{*}\end{array}$ & & \\
\hline priv credit*shock $_{t}$ & $\begin{array}{l}0.0337 \\
(0.47)\end{array}$ & $\begin{array}{l}0.0685 \\
(0.67)\end{array}$ & $\begin{array}{l}0.0394 \\
(0.54)\end{array}$ & $\begin{array}{l}0.0403 \\
(0.37)\end{array}$ & $\begin{array}{l}0.0815 \\
(0.71)\end{array}$ & $\begin{array}{l}-0.0830 \\
(-0.76)\end{array}$ & $\begin{array}{l}-0.0740 \\
(-0.70)\end{array}$ \\
\hline priv credit $^{*}$ shock $_{t-1}$ & $\begin{array}{l}-0.0177 \\
(-0.27)\end{array}$ & $\begin{array}{l}-0.0086 \\
(-0.08)\end{array}$ & $\begin{array}{l}-0.0127 \\
(-0.14)\end{array}$ & $\begin{array}{l}0.0388 \\
(0.26)\end{array}$ & $\begin{array}{l}0.0150 \\
(0.11)\end{array}$ & $\begin{array}{l}-0.1516 \\
(-1.16)\end{array}$ & $\begin{array}{l}-0.0896 \\
(-0.70)\end{array}$ \\
\hline priv credit $^{*}$ shock $_{t-2}$ & $\begin{array}{l}-0.2083 \\
(-3.05)^{\star \star *}\end{array}$ & $\begin{array}{l}-0.2544 \\
(-2.26)^{\star *}\end{array}$ & $\begin{array}{l}-0.1514 \\
(-1.82)^{*}\end{array}$ & $\begin{array}{l}-0.2382 \\
(-1.94)^{*}\end{array}$ & $\begin{array}{l}-0.2240 \\
(-1.90)^{*}\end{array}$ & $\begin{array}{l}-0.2563 \\
(-2.59)^{\star *}\end{array}$ & $\begin{array}{l}-0.2515 \\
(-2.52)^{\star *}\end{array}$ \\
\hline $\begin{array}{l}\text { Controls: } \\
\text { income }_{t-2}\end{array}$ & yes & yes & yes & yes & yes & yes & yes \\
\hline country fixed effects & yes & yes & yes & yes & yes & yes & yes \\
\hline property rights and interactions & no & yes & no & yes & yes & yes & yes \\
\hline income interactions & no & no & yes & yes & yes & yes & yes \\
\hline year fixed effects & no & no & no & no & yes & no & yes \\
\hline $\begin{array}{l}\text { F-tests: } \\
\text { all credit interaction terms } \\
\text { lagged credit interaction terms }\end{array}$ & $\begin{array}{l}0.0164 \\
0.0074\end{array}$ & $\begin{array}{l}0.0636 \\
0.0359\end{array}$ & $\begin{array}{l}0.2950 \\
0.1992\end{array}$ & $\begin{array}{l}0.1972 \\
0.1063\end{array}$ & $\begin{array}{l}0.2116 \\
0.1390\end{array}$ & $\begin{array}{l}0.0765 \\
0.0375\end{array}$ & $\begin{array}{l}0.0847 \\
0.0490\end{array}$ \\
\hline $\begin{array}{l}R \text {-squared } \\
\# \text { countries } \\
N\end{array}$ & $\begin{array}{l}0.1739 \\
65 \\
1,923\end{array}$ & $\begin{array}{l}0.2383 \\
53 \\
1,044 \\
\end{array}$ & $\begin{array}{l}0.1745 \\
65 \\
1,923\end{array}$ & $\begin{array}{l}0.2397 \\
53 \\
1,044\end{array}$ & $\begin{array}{l}0.2993 \\
53 \\
1,044\end{array}$ & $\begin{array}{l}0.1513 \\
57 \\
2,109 \\
\end{array}$ & $\begin{array}{l}0.1979 \\
57 \\
2,109 \\
\end{array}$ \\
\hline
\end{tabular}

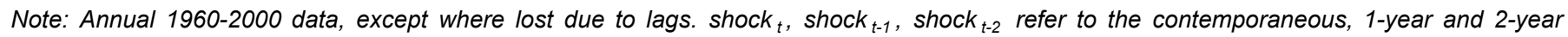
lagged commodity price shock. All regressions include a constant term, and cluster errors at the country level. The sample is limited to countries whose $(t-5, t-1)$ credit average is always above $10 \%$ of GDP. Private credit and the property rights terms are averaged as indicated in the column heading. Income interactions use twice lagged per capita income in Columns (1)-(5) and the 1960-2000 average in Columns (6)-(7). $t$ statistics in parenthesis. ${ }^{* * *},{ }^{* *},{ }^{*}$ significant at $1 \%, 5 \%$, and $10 \%$. 
Table 5. The response of R\&D to commodity price shocks

Dependent variable: R\&D/investment

\begin{tabular}{|c|c|c|c|c|c|c|}
\hline \multirow{2}{*}{$\begin{array}{l}\text { Private credit and property } \\
\text { terms average: }\end{array}$} & \multicolumn{3}{|c|}{$(\mathrm{t}-5, \mathrm{t}-1)$ avg } & \multicolumn{3}{|c|}{ 1973-1999 avg } \\
\hline & $(1)$ & $(2)$ & (3) & (4) & $(5)$ & (6) \\
\hline shock $_{t}$ & $\begin{array}{l}0.0903 \\
(0.34)\end{array}$ & $\begin{array}{l}1.2825 \\
(0.38)\end{array}$ & $\begin{array}{l}3.5864 \\
(0.87)\end{array}$ & $\begin{array}{l}0.2175 \\
(0.54)\end{array}$ & $\begin{array}{l}2.5729 \\
(0.18)\end{array}$ & $\begin{array}{l}5.0466 \\
(0.33)\end{array}$ \\
\hline shock $_{t-1}$ & $\begin{array}{l}-0.1156 \\
(-0.51)\end{array}$ & $\begin{array}{l}5.7272 \\
(2.74)^{\star *}\end{array}$ & $\begin{array}{l}3.0835 \\
(0.86)\end{array}$ & $\begin{array}{l}0.3550 \\
(0.97)\end{array}$ & $\begin{array}{l}12.3290 \\
(1.13)\end{array}$ & $\begin{array}{l}24.5633 \\
(2.15)^{\star}\end{array}$ \\
\hline shock $_{t-2}$ & $\begin{array}{l}0.3867 \\
(1.29)\end{array}$ & $\begin{array}{l}7.2179 \\
(1.66)\end{array}$ & $\begin{array}{l}1.6775 \\
(0.42)\end{array}$ & $\begin{array}{l}0.1002 \\
(0.23)\end{array}$ & $\begin{array}{l}7.1779 \\
(0.78)\end{array}$ & $\begin{array}{l}13.4177 \\
(0.96)\end{array}$ \\
\hline priv credit & $\begin{array}{l}0.0654 \\
(0.31)\end{array}$ & $\begin{array}{l}0.0365 \\
(0.24)\end{array}$ & $\begin{array}{l}0.0252 \\
(0.16)\end{array}$ & & & \\
\hline 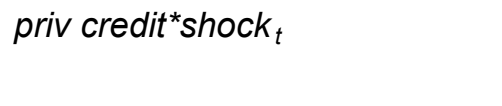 & $\begin{array}{l}-0.2010 \\
(-0.51)\end{array}$ & $\begin{array}{l}-0.0233 \\
(-0.07)\end{array}$ & $\begin{array}{l}-0.0887 \\
(-0.34)\end{array}$ & $\begin{array}{l}-0.3391 \\
(-0.63)\end{array}$ & $\begin{array}{l}-0.5424 \\
(-0.57)\end{array}$ & $\begin{array}{l}-0.7318 \\
(-0.84)\end{array}$ \\
\hline priv credit $^{*}$ shock $_{t-1}$ & $\begin{array}{l}0.0692 \\
(0.15)\end{array}$ & $\begin{array}{l}0.1214 \\
(0.40)\end{array}$ & $\begin{array}{l}0.0663 \\
(0.19)\end{array}$ & $\begin{array}{l}-0.5605 \\
(-0.90)\end{array}$ & $\begin{array}{l}-0.8399 \\
(-0.94)\end{array}$ & $\begin{array}{l}-1.2364 \\
(-2.05)^{\star}\end{array}$ \\
\hline priv credit $^{*}$ shock $_{t-2}$ & $\begin{array}{l}-0.8823 \\
(-1.56)\end{array}$ & $\begin{array}{l}-0.9269 \\
(-1.45)\end{array}$ & $\begin{array}{l}-1.0567 \\
(-1.90)^{*}\end{array}$ & $\begin{array}{l}-0.3538 \\
(-0.52)\end{array}$ & $\begin{array}{l}-0.9251 \\
(-0.93)\end{array}$ & $\begin{array}{l}-2.2883 \\
(-2.16)^{\star *}\end{array}$ \\
\hline $\begin{array}{l}\text { Controls: } \\
\text { income }_{t-2}\end{array}$ & & & & & & \\
\hline $\begin{array}{l}\text { Income }_{t-2} \\
\text { country fixed effects }\end{array}$ & $\begin{array}{l}\text { yes } \\
\text { yes }\end{array}$ & $\begin{array}{l}\text { yes } \\
\text { yes }\end{array}$ & $\begin{array}{l}\text { yes } \\
\text { yes }\end{array}$ & $\begin{array}{l}\text { yes } \\
\text { yes }\end{array}$ & $\begin{array}{l}\text { yes } \\
\text { yes }\end{array}$ & $\begin{array}{l}\text { yes } \\
\text { yes }\end{array}$ \\
\hline property rights and interactions & no & yes & yes & no & yes & yes \\
\hline income interactions & no & yes & yes & no & yes & yes \\
\hline year fixed effects & no & no & yes & no & no & yes \\
\hline $\begin{array}{l}\text { F-tests: } \\
\text { all credit interaction terms } \\
\text { lagged credit interaction terms }\end{array}$ & $\begin{array}{l}0.4076 \\
0.2497\end{array}$ & $\begin{array}{l}0.1677 \\
0.3181\end{array}$ & $\begin{array}{l}0.3193 \\
0.2023\end{array}$ & $\begin{array}{l}0.6837 \\
0.4878\end{array}$ & $\begin{array}{l}0.7677 \\
0.6396\end{array}$ & $\begin{array}{l}0.0860 \\
0.1296\end{array}$ \\
\hline $\begin{array}{l}R \text {-squared } \\
\# \text { countries } \\
N \\
\end{array}$ & $\begin{array}{l}0.8396 \\
14 \\
342\end{array}$ & $\begin{array}{l}0.9205 \\
14 \\
307\end{array}$ & $\begin{array}{l}0.9303 \\
14 \\
307\end{array}$ & $\begin{array}{l}0.8482 \\
14 \\
357\end{array}$ & $\begin{array}{l}0.8534 \\
14 \\
357\end{array}$ & $\begin{array}{l}0.8909 \\
14 \\
357\end{array}$ \\
\hline
\end{tabular}

Note: Annual 1973-1999 data, except where lost due to lags. shock ${ }_{t}$, shock ${ }_{t-1}$, shock ${ }_{t-2}$ refer to the contemporaneous, 1-year and 2-year lagged commodity price shock. All regressions include a constant term, and cluster errors at the country level. Private credit and the property rights terms are averaged as indicated in the column heading. Income interactions use twice lagged per capita income in Columns (1)-(3) and the 1973-1999 average in Columns (4)-(6). t-statistics in parenthesis. ${ }^{* * *},{ }^{* *},{ }^{*}$ significant at $1 \%, 5 \%$, and $10 \%$. 
Table 6. The response of investment to commodity price shocks

Dependent variable: Investment/GDP

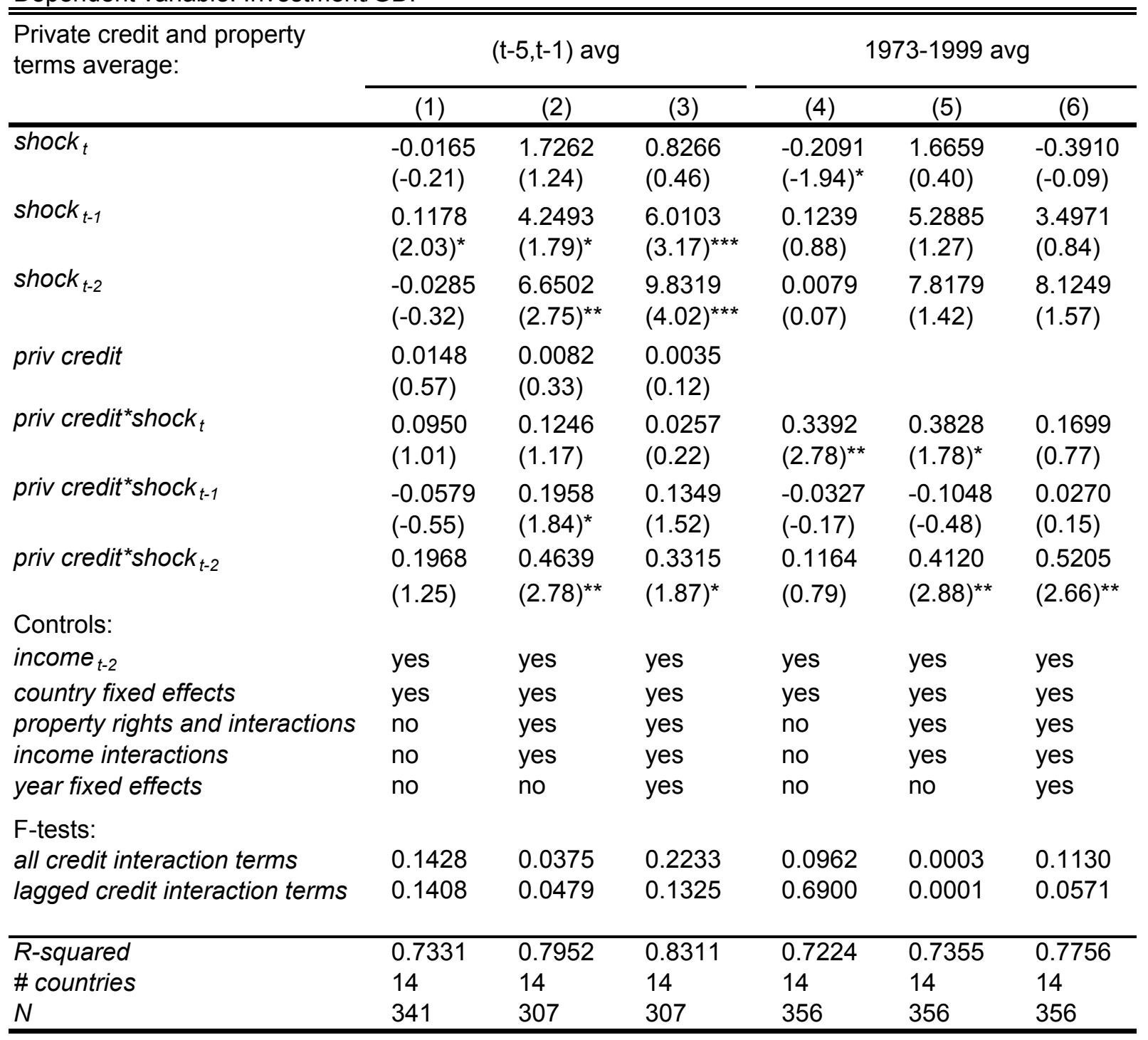

Note: Annual 1973-1999 data, except where lost due to lags. Sample limited to coutry-year observations with R\&D data, as in Table 5. shock ${ }_{t}$, shock $t_{t-1}$, shock ${ }_{t-2}$ refer to the contemporaneous, 1-year and 2-year lagged commodity price shock. All regressions include a constant term, and cluster errors at the country level. Private credit and the property rights terms are averaged as indicated in the column heading. Income interactions use twice lagged per capita income in Columns (1)-(3) and the 1973-1999 average in Columns (4)-(6). t-statistics in parenthesis. ${ }^{* * *, * *},{ }^{*}$ significant at $1 \%, 5 \%$, and $10 \%$. 
Table 7. Growth, volatility and credit constraints

Dependent variable: avg. growth, 1960-1995

\begin{tabular}{|c|c|c|c|c|c|c|c|c|}
\hline & \multicolumn{4}{|c|}{ OLS } & \multicolumn{4}{|c|}{ IV: commodity price shocks volatility } \\
\hline & \multicolumn{2}{|c|}{ No investment } & \multicolumn{2}{|c|}{ With investment } & \multicolumn{2}{|c|}{ No investment } & \multicolumn{2}{|c|}{ With investment } \\
\hline & $(1)$ & $(2)$ & (3) & $(4)$ & $(5)$ & (6) & $(7)$ & $(8)$ \\
\hline initial income & $\begin{array}{l}-0.0090 \\
(-2.85)^{\star * *}\end{array}$ & $\begin{array}{l}-0.0182 \\
(-5.02)^{\star \star *}\end{array}$ & $\begin{array}{l}-0.0109 \\
(-4.04)^{* * *}\end{array}$ & $\begin{array}{l}-0.0160 \\
(-4.93)^{\star \star \star}\end{array}$ & $\begin{array}{l}-0.0276 \\
(-0.90)\end{array}$ & $\begin{array}{l}-0.0371 \\
(-0.44)\end{array}$ & $\begin{array}{l}-0.0267 \\
(-0.68)\end{array}$ & $\begin{array}{l}-0.0120 \\
(-0.39)\end{array}$ \\
\hline growth volatility & $\begin{array}{l}-0.8763 \\
(-3.54)^{\star * *}\end{array}$ & $\begin{array}{l}-0.7260 \\
(2.80)^{\star * *}\end{array}$ & $\begin{array}{l}-0.6941 \\
(-3.27)^{\star * *}\end{array}$ & $\begin{array}{l}-0.5772 \\
(-2.51)^{\star \star}\end{array}$ & $\begin{array}{l}-6.0000 \\
(-0.63)\end{array}$ & $\begin{array}{l}-5.8680 \\
(-0.26)\end{array}$ & $\begin{array}{l}-5.7602 \\
(-0.40)\end{array}$ & $\begin{array}{l}-0.0495 \\
(-0.01)\end{array}$ \\
\hline private credit & $\begin{array}{l}-0.00037 \\
(-1.80)^{*}\end{array}$ & $\begin{array}{l}0.00023 \\
(0.57)\end{array}$ & $\begin{array}{l}-0.00034 \\
(-1.94)^{*}\end{array}$ & $\begin{array}{l}0.00007 \\
(0.19)\end{array}$ & $\begin{array}{l}-0.0032 \\
(-0.46)\end{array}$ & $\begin{array}{l}-0.0023 \\
(-0.24)\end{array}$ & $\begin{array}{l}-0.0031 \\
(-0.35)\end{array}$ & $\begin{array}{l}-0.0001 \\
(-0.07)\end{array}$ \\
\hline volatility ${ }^{*}$ private credit & $\begin{array}{l}0.0184 \\
(3.19)^{\star * *}\end{array}$ & $\begin{array}{l}0.0129 \\
(2.30)^{\star *}\end{array}$ & $\begin{array}{l}0.0134 \\
(2.68)^{\star *}\end{array}$ & $\begin{array}{l}0.0097 \\
(1.95)^{\star}\end{array}$ & $\begin{array}{l}0.0939 \\
(0.46)\end{array}$ & $\begin{array}{l}0.0725 \\
(0.26)\end{array}$ & $\begin{array}{l}0.0910 \\
(0.35)\end{array}$ & $\begin{array}{l}0.0062 \\
(0.09)\end{array}$ \\
\hline investment/GDP & & & $\begin{array}{l}0.1356 \\
(4.28)^{\star * *}\end{array}$ & $\begin{array}{l}0.0964 \\
(3.16)^{\star * *}\end{array}$ & & & $\begin{array}{l}0.0174 \\
(0.04)\end{array}$ & $\begin{array}{l}0.1286 \\
(0.53)\end{array}$ \\
\hline Controls: & & & & & & & & \\
\hline pop growth, sec enroll & no & yes & no & yes & no & yes & no & yes \\
\hline Levine et al. policy set & no & yes & no & yes & no & yes & no & yes \\
\hline property rights & no & yes & no & yes & no & yes & no & yes \\
\hline private $_{\text {credit }}{ }^{2}$ & no & yes & no & yes & no & no & no & no \\
\hline F-test (volatility terms) & 0.0039 & 0.0303 & 0.0087 & 0.0526 & 0.7651 & 0.9028 & 0.9028 & 0.8654 \\
\hline F-test (credit terms) & 0.0005 & 0.0052 & 0.0218 & 0.0506 & 0.8982 & 0.9403 & 0.9403 & 0.8776 \\
\hline$R$-squared & 0.3721 & 0.7467 & 0.5659 & 0.8151 & & & & \\
\hline$N$ & 47 & 42 & 47 & 42 & 47 & 42 & 47 & 42 \\
\hline
\end{tabular}

Note: All regressors are averages over the 1960-1995 period, except for intellectual and property rights which are for 1970-1995 and 19701990 respectively. Initial income and secondary school enrollment are taken for 1960. Growth and commodity price shocks volatility are constructed as the standard deviation of annual growth and commodity price shocks in the 1960-1995 period respectively. The sample is limited to the same set of countries as in Tables 3 and 4 (countries whose $(t-5, t-1)$ credit average is always above $10 \%$ of GDP). The Levine et al. policy set of controls includes government size as a share of GDP, inflation, black market premium, and trade openness. Constant term not shown. $t$-statistics in parenthesis. ${ }^{* * *},{ }^{* *},{ }^{*}$ significant at $1 \%, 5 \%$, and $10 \%$. 